\title{
Review article: Extreme marine events revealed by lagoonal sedimentary records in Ghar El Melh during the last 2500 years in the northeast of Tunisia
}

\author{
Balkis Samah Kohila $^{1,2}$, Laurent Dezileau ${ }^{2}$, Soumaya Boussetta ${ }^{1}$, Tarek Melki ${ }^{1}$, and Nejib Kallel ${ }^{1}$ \\ ${ }^{1}$ Laboratoire Géoressources, Matériaux, Environnements et changements globaux, LR13ES23 (GEOGLOB), \\ Faculté des Sciences de Sfax, Université de Sfax, BP1171, Sfax 3000, Tunisia \\ ${ }^{2}$ Laboratoire de Morphodynamique Continentale et Côtière (M2C), Université de Caen, UMR 6143, 14000 Caen, France
}

Correspondence: Balkis Samah Kohila (balkis.samah@yahoo.fr)

Received: 16 September 2020 - Discussion started: 3 November 2020

Revised: 7 September 2021 - Accepted: 1 November 2021 - Published: 2 December 2021

\begin{abstract}
The Tunisian coast has been affected in the past by many events of extreme marine submersion (storms and tsunamis). A high-resolution study along two sediment cores taken from the lagoon of Ghar El Meleh was performed to identify the different paleoextreme events and to reconstruct the paleoenvironmental changes in the northeastern part of Tunisia during the Late Holocene. A very high-resolution sedimentological analysis (granulometric and geochemical) was applied to these cores. These cores were also dated with isotopic techniques $\left({ }^{137} \mathrm{Cs},{ }^{210} \mathrm{~Pb}_{\mathrm{ex}},{ }^{14} \mathrm{C}\right)$, and the outcomes reveal five phases of paleoenvironmental changes in this lagoonal complex and identify two sediment layers that are in connection with two major historical marine submersion events. The first layer is mentioned as E1 and seems to fit with the great tsunami of $365 \mathrm{calCE}$. This event was marked by an increase in the coarse sediment, and it is correlated for the first time with the immersed city of Neapolis in the northern Gulf of Hammamet discovered in 2017 by the same tsunamis of $365 \mathrm{calCE}$. The other sandy layer, referred to as E2, was dated from 1690 to $1760 \mathrm{calCE}$ and is marked by one specific sedimentological layer attributed to a marine submersion event. This layer could be associated with the 1693 tsunami event in southern Italy or an increase in extreme storm events.
\end{abstract}

\section{Introduction}

During the last century, coastal communities have become very vulnerable to many extreme events such as tsunamis, tropical storms, hurricanes, and floods (Chaumillon et al., 2017). Risks and vulnerabilities of the coastal area have recently increased not only because of the sea-level rise and the changes in climate conditions but also because of the high number of natural catastrophes and the construction of nonplanned urban areas (Cardona, 2002; Milanés Batista et al., 2017).

However, coastal storm or tsunami hazards are among the most dangerous events that caused significant human and economic losses along coastal regions (Seisdedos et al., 2013). One of the most destructive recorded meteorological events was Hurricane Katrina in Florida, in the United States, in 2005. It engenders more than USD 100 billion of damages, killed around 2000 people, and touched 90000 square miles $\left(233098 \mathrm{~km}^{2}\right)$ of the United States (Phadke, 2005). The 2004 Sumatra tsunami was associated with a megaearthquake with $M_{\mathrm{w}} 9.2$. This tsunami has generated high waves up to $30 \mathrm{~m}$ and caused 250000 deaths (Paris et al., 2010). This tsunami was considered the most hazardous event compared to other past catastrophic events that occurred in 1797 and 1833 on the coast of Sumatra island (Ahmadun et al., 2020).

The Mediterranean basin is defined as a "hotspot" of climate change (Lionello and Scarascia, 2018; Pausas and Millán, 2019). According to the IPCC (2014), the coastal erosion and submersion are some of the results of an el- 
evation of sea level due to global warming. The Mediterranean Sea surface temperature has increased by almost $1{ }^{\circ} \mathrm{C}$ since 1980 and is expected to rise further by $2.5^{\circ} \mathrm{C}$ in the next 70 years (Karas, 1997). In this context, the Mediterranean coastal zones will probably be more vulnerable to climatic extreme events (storms and medicanes) and more exposed to coastal erosion processes and flooding (Seisdedos et al., 2013). The Mediterranean basin is also characterized by a high seismic activity due to its geographical position between the Eurasian and African plates (Papadopoulos and Fokaefs, 2005; Papadopoulos and Baskoutas, 2009). The earthquake of 21 May 2003 that happened in the western Mediterranean sub-basin precisely in Boumerdes (Algeria) with a magnitude of about $M_{\mathrm{w}} 6.9$ generated a tsunami (Sahal et al., 2009). The wave generated had a height $<25 \mathrm{~cm}$ and propagated from the Algerian coast toward Murcia Province. These waves did not cause any evident damages (Álvarez-Gómez and Gonzalez, 2011). However, in the eastern Mediterranean sub-basin, the Crete earthquake (21 July 365 CE) induced a tsunami that propagated across the region to reach Alexandria and hit the Cretan coast, causing extensive damage (Scardino et al., 2020).

The Tunisian coast has been exposed to numerous extreme hazards (floods, storms, and tsunamis) (Rizzi et al., 2016; Zaïbi et al., 2016; Affouri et al., 2017; Khadraoui et al., 2018; Amrouni et al., 2019). During the last century, this coastal area has experienced some coastal marine storms (Zaïbi et al., 2016). Moreover, this area is also subject to tsunami events, which can especially come from the seismic source related to the tectonic activities in southeastern Sicily; e.g., the immersed city of Neapolis in the northern Gulf of Hammamet discovered in 2017 suggests the occurrence of a tsunami in 365 CE (Aounallah and Fantar, 2006; INP, 2017).

Due to the absence of high-resolution data covering a sufficiently long time period, the recent instrumental data and textual archive on extreme events in Tunisia do not allow us to determine any evolution in time. Since these extreme hazards (storm and tsunami) are causing many sedimentary inputs in coastal areas, the recent geological records existing in this area will allow the study of these extreme events over a longer time beyond the textural and instrumental textural archives (Morton et al., 2007; Dezileau et al., 2011; Sabatier et al., 2012). This geological approach using sedimentological and geochemical analyses has been used in the French, Moroccan, and Spanish coasts (Degeai et al., 2015; Dezileau et al., 2016; Khalfaoui et al., 2019). Inversely, only a few high-resolution studies have been conducted on the Tunisian coast. In this context, the present study aims to reconstruct past marine submersion events from geological archives (GEM3 and GEM4 cores) collected from the Ghar El Meleh lagoon (northeast of Tunisia) using a highresolution sedimentological and geochemical analysis.

\section{The study site of Ghar El Meleh}

\subsection{Geological and geomorphological setting}

This work focuses on the Ghar El Meleh lagoon situated in the northeast of Tunisia. This lagoon is also called "the Porto Farina". It has an elliptic shape and a surface of approximately $28.5 \mathrm{~km}^{2}$. Its average depth is about $\sim 0.8 \mathrm{~m}$ (Romdhane, 1985; SCET-ERI, 2000; Moussa et al., 2005). This lagoon is directly limited on the northern side by a mountain range called "Jbel Nadhour" ( $325 \mathrm{~m}$ ). This mountain is composed of a marine Pliocene material (Fig. 1) represented by sandstone sediments (Hamouda, 2011). The lagoon is bordered on the western and southern side by recent quaternary marshy grounds formed by clay and silt sediments. On the eastern side, it is separated from the sea by a sandy barrier, with a local opening (El Boughaz) allowing a permanent hydraulic communication (Oueslati et al., 2006). This sandy barrier was formed by a littoral drift oriented from the northeast to the southwest (KHRYSTAL Engineering, 2003).

According to Paskoff (1994), the lagoon was considered to be a vestigial and remains part of the old bay of Utica that was formed during the last postglacial transgression 6000 years ago. Progressively, this small gulf has been disconnected from the old bay of Utica due to Medjerda fluvial deposits (Paskoff and Trousset, 1992). This caused a progressive reshaping of the lagoon to its present morphology, which could be attributed to an association of the shape of the coastline and alluvium deposition from the Medjerda River (Moussa et al., 2005). Over time, the delta of the Medjerda was distinguished by a high interannual discharge variability. This river's average sediment yield is about $10 \mathrm{~g} \mathrm{~L}^{-1}$, and it is characterized by an annual average flow of $30 \mathrm{~m}^{3} \mathrm{~s}^{-1}$ and reached $3500 \mathrm{~m}^{3} \mathrm{~s}^{-1}$ in the exceptional flood of March 1973, where solid discharge is calculated around $100 \mathrm{~g} \mathrm{~L}^{-1}$ (Claude et al., 1977). A large amount of alluvium was carried by the Oued, estimated at over 22 million tonnes per year in the Gulf of Tunis before the construction of dams (Oueslati et al., 2006). The sediments are deposited when the Oued reaches the low flood zones, contributing then to an extension of its delta towards the sea and numerous changes in channels (Delile et al., 2015).

In the Gulf of Tunis, the mean amplitude of semi-diurnal micro-tidal activities measures between 12 and $30 \mathrm{~cm}$ (El Arrim, 1996; Saïdi et al., 2012). The amplitude of the tidal range in this region was estimated at around $35 \mathrm{~cm}$ (Oueslati, 1993). The coastal environment of the Gulf of Tunis was exposed to natural erosion processes induced by waves, tides, and periodic storm surges (Hzami et al., 2021). This erosion is the effect of the long shore coastal drift from the southeastto-northwest direction. 

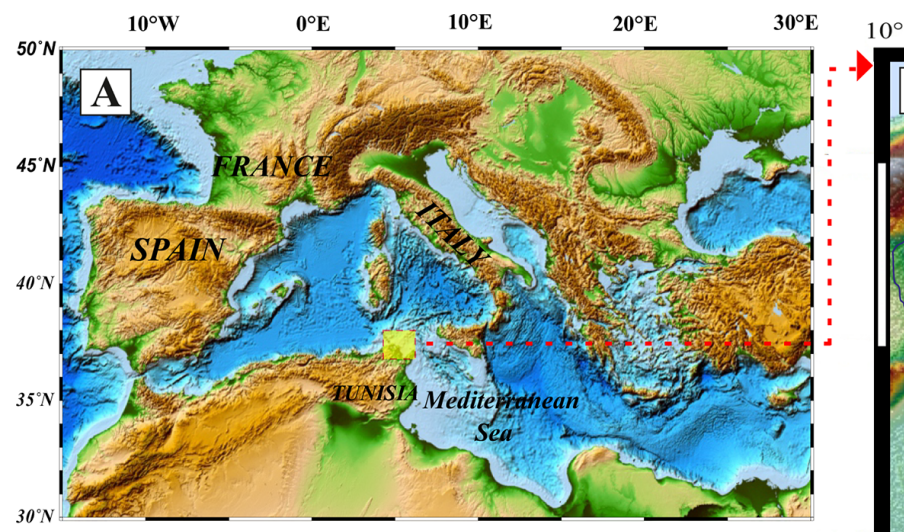

$10^{\circ} 130 " \mathrm{E} \quad 10^{\circ} 7^{\prime} 0^{\prime \prime} \mathrm{E} \quad 10^{\circ} 12^{\prime} 30^{\prime \prime} \mathrm{E} \quad 10^{\circ} 18^{\prime} 0^{\prime \prime} \mathrm{E}$

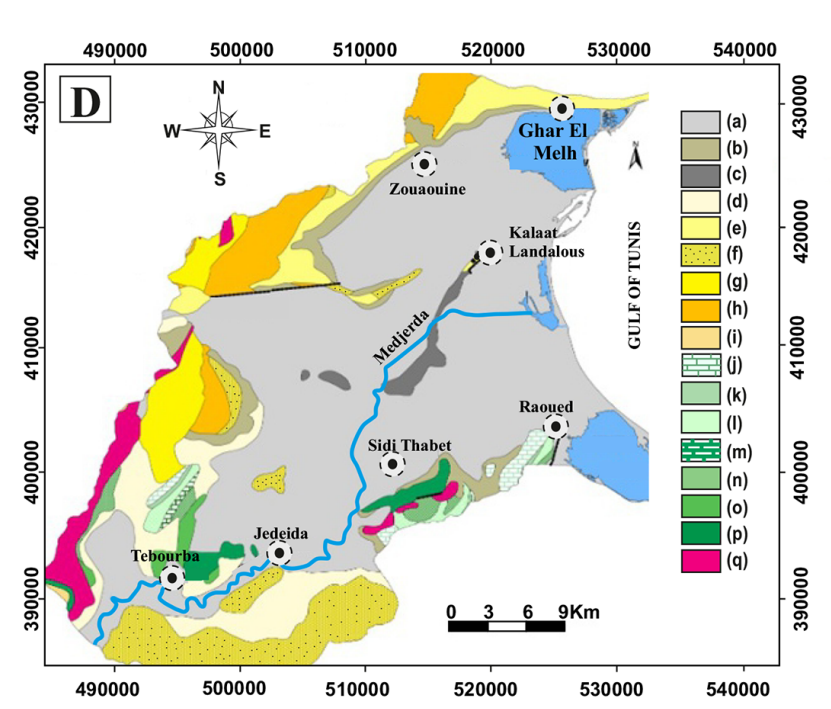

(ô.) main cities

$\square$ GEM3 and GEM4 cores in the Sidi Ali Mekki lagoon Samples in the Medjerda watershed
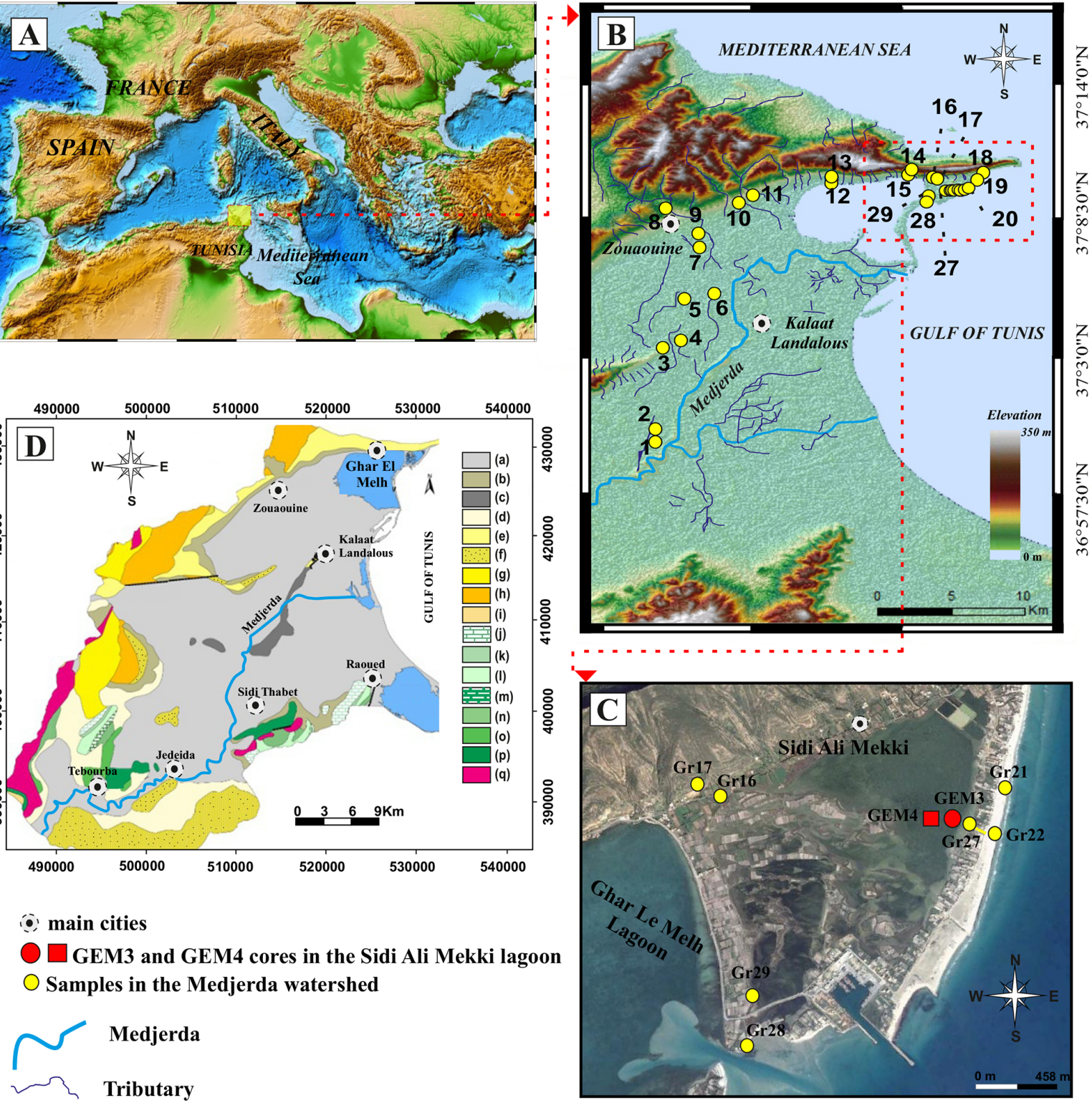

Figure 1. Maps of geographic setting of the Ghar El Meleh lagoon. (A) Position of the studied region in the northeastern Mediterranean (Word Ocean Atlas 2013, http://odv.awi.de/de/data/ocean/worldoceanatlas2013, last access: 1 December 2021). (B) Topographic map of the lagoon and the emplacement of the different surface sediment samples taken from the coastal plain of the Medjerda (created by Radewane Hout using ArcGIS). (C) Topographic map of the Ghar El Meleh lagoon and its surroundings (e.g., (C) Google Earth). (D) Geological maps of the Medjerda watershed - (a) recent alluvial soils, (b) slope deposits, (c) marine Quaternary, (d) Villafranchian, (e) Pliocene, (f) Continental Pliocene, (g) Upper Miocene, (h) detrital sediment deposit from Kchabta (i) Lower Eocene, (j) Maastrichtian, (k) Senonian, (l) Cenomanian, (m) Albian, (n) Aptian, (o) Barremian, (p) Valanginian-Hauterivian, (q) Triassic - (geological map; paper no. II of Bizerte at $1: 200000$ modified from Hamouda, 2011).

\subsection{Climatological and hydrological settings}

The northeast of Tunisia is characterized by a typical Mediterranean climate with arid summers and rainy winters, characterized generally by heavy rainfall periods and floods. The mean annual rainfall in the lower valley of the Medjerda is around $500 \mathrm{~mm} \mathrm{yr}^{-1}$ (Oueslati, 2004). Furthermore, in this study area, the rainfall rate is very variable. The mean winter temperatures are around $\sim 11^{\circ} \mathrm{C}$. The highest precipitation occurs mainly between November and December, with an average of $248 \mathrm{~mm}$ (INS, 2014). The monthly average values sometimes exceed $100 \mathrm{~mm}$ (Beni Atta Station in December) and never fall below $60 \mathrm{~mm}$ (MEAT, 2001). The high temperatures are observed in August, with mean values of 
$\sim 27^{\circ} \mathrm{C}$. On the other hand, the salinity in the lagoon depends on the hydrological balance and varies from $36 \mathrm{~g} \mathrm{~L}^{-1}$ in winter to $51 \mathrm{~g} \mathrm{~L}^{-1}$ in summer due to the higher evaporation rate (1450 $\mathrm{mm} \mathrm{yr}^{-1}$ ) (Added, 2001; Moussa et al., 2005; Oueslati et al., 2006).

\section{Material and methods}

\subsection{Sampling location and sediment samples}

Two piston cores were manually collected in 2012 in the northeast of Ghar El Meleh lagoon. These cores are $126 \mathrm{~cm}$ (GEM4) and $98 \mathrm{~cm}$ (GEM3) in length and $10 \mathrm{~cm}$ in diameter (Fig. 1). They were manually sampled from an east-west transect in the lagoon $(\sim 200 \mathrm{~m}$ from the sandy barrier for GEM3 and $\sim 400 \mathrm{~m}$ for GEM4). In the laboratory, the two cores GEM4 and GEM3 were photographed and described in detail. Before granulometric and geochemical analysis, the cores were split into $1 \mathrm{~cm}$ vertical sections. Moreover, 29 surface sediment samples of around 20 to $30 \mathrm{~g}$ were collected from present-day soil horizons from the Medjerda watershed to the littoral area (beaches and dunes) to assess the origin and all sources of the lagoon sediment arriving in the study area: (i) 6 samples come from the Medjerda River (Gr01 to Gr06), (ii) 12 samples from different small affluents located in the northern and western part of the lagoon (from $\mathrm{Gr} 07$ to Gr18), and (iii) 11 samples from the sandy barrier (Gr19 to Gr29) (Fig. 1). In the laboratory, granulometric and geochemical analysis was performed on these surface samples. The particle sizes obtained are classified according to Folk and Ward (1957) into three categories (clay $\Phi<2 \mu \mathrm{m}$, silt $2 \mu \mathrm{m}<\Phi<63 \mu \mathrm{m}$, and sand $\Phi>63 \mu \mathrm{m}$ ).

\subsection{Sedimentology and geochemistry analysis}

To determine the distribution of grain size a particle size analysis was adopted by using a Beckman Coulter @ LS 13320 (Geosciences Montpellier). Due to the high concentration of shell fragments $(>200 \mu \mathrm{m})$, every sample was sieved at $150 \mu \mathrm{m}$ before analysis. An ultrasound was used to avoid particle flocculation after the entrance of sediments into the fluid module of the device. The elemental geochemical analyses by energy-dispersive X-ray fluorescence (XRF) spectrometry were undertaken on sediment cores and surface samples with a handheld Niton XL3t. In order to avoid desiccation of the sediment and contamination of the XRF measurement unit, samples had to be covered with an Ultralene film. The geochemical analysis from XRF measurements was executed in the mining type ModCF proline mode. These semiquantitative elemental measurements were performed along with the sediment core every $1 \mathrm{~cm}$. The elemental concentrations obtained in this work using the handheld Nitron XL3t are expressed in parts per million or percentage values.

\subsection{Chronological framework}

The chronology of the two cores for the last century was measured using ${ }^{210} \mathrm{~Pb}_{\mathrm{ex}}$ and ${ }^{137} \mathrm{Cs}$ measurements with a CANBERRA Broad Energy Ge (BEGe) detector on fine sediment (fraction $<150 \mu \mathrm{m}$ ). The ${ }^{210} \mathrm{~Pb}_{\mathrm{ex}}$ dating is founded on the determination of the ${ }^{210} \mathrm{~Pb}$ excess activities preserved in the sediment of cores. The use of this natural radionuclide ${ }^{210} \mathrm{~Pb}$ to indicate sedimentation rate is now a wellestablished technique (Goldberg, 1963; Krishnaswamy et al., 1971; Robbins and Edgington, 1975). The dating of ${ }^{137} \mathrm{Cs}$ was released following the procedure of Robbins and Edgington (1975). To complete the chronology of the two cores over longer periods of time, ${ }^{14} \mathrm{C}$ analyses were performed on mollusk species (Cerastoderma glaucum) at the Laboratoire de Mesure C14 (LMC14) on the ARTEMIS accelerator of the French CEA (Atomic Energy Commission) in Saclay, France. In fact, these ${ }^{14} \mathrm{C}$ analyses were realized with the classical procedure illustrated by Tisnérat-Laborde et al. (2001). The radiocarbon ages were transformed into calendar ages utilizing the Marine13 curve (Reimer et al., 2013). The radiocarbon ages of marine and lagoonal organisms are generally older than the atmospheric ${ }^{14} \mathrm{C}$ ages and have been calculated and modified by subtracting the "reservoir age" (Zoppi et al., 2001; Siani et al., 2001; Reimer and McCormac, 2002; Sabatier et al., 2010; Dezileau et al., 2016).

\section{Results}

\subsection{Downcore results}

\subsubsection{Lithological, granulometric, and geochemical studies of GEM3 and GEM4 cores}

Two sedimentary cores were collected in the northeastern part of Ghar El Meleh lagoon. They contain fine sediments (clay and silt) interbedded with coarse-grained layers formed by mollusk fragments and siliciclastic sand. The sedimentary succession in the GEM3 core is very comparable to that presented in GEM4 (Fig. 2). The thickness of sandy layers is slightly different between the two cores. This could be attributed to the geographical position of core GEM3, which is closer to the sandy barrier $(\sim 200 \mathrm{~m})$ than core GEM4 ( $\sim 400 \mathrm{~m})$.

The 97 and $126 \mathrm{~cm}$ long GEM3 and GEM4 sediment cores show visual variation in the sediment composition. Lithological description of these two cores highlighted five distinct sedimentary facies (Fig. 2):

- The first unit (1), situated between 126-67 cm in GEM4 and between $97-85 \mathrm{~cm}$ in GEM3, is composed generally of a light-gray silt layer and shells. At the base (the last $3 \mathrm{~cm}$ for GEM3 and the last $13 \mathrm{~cm}$ for GEM4), the lithological composition of this unit is characterized by 

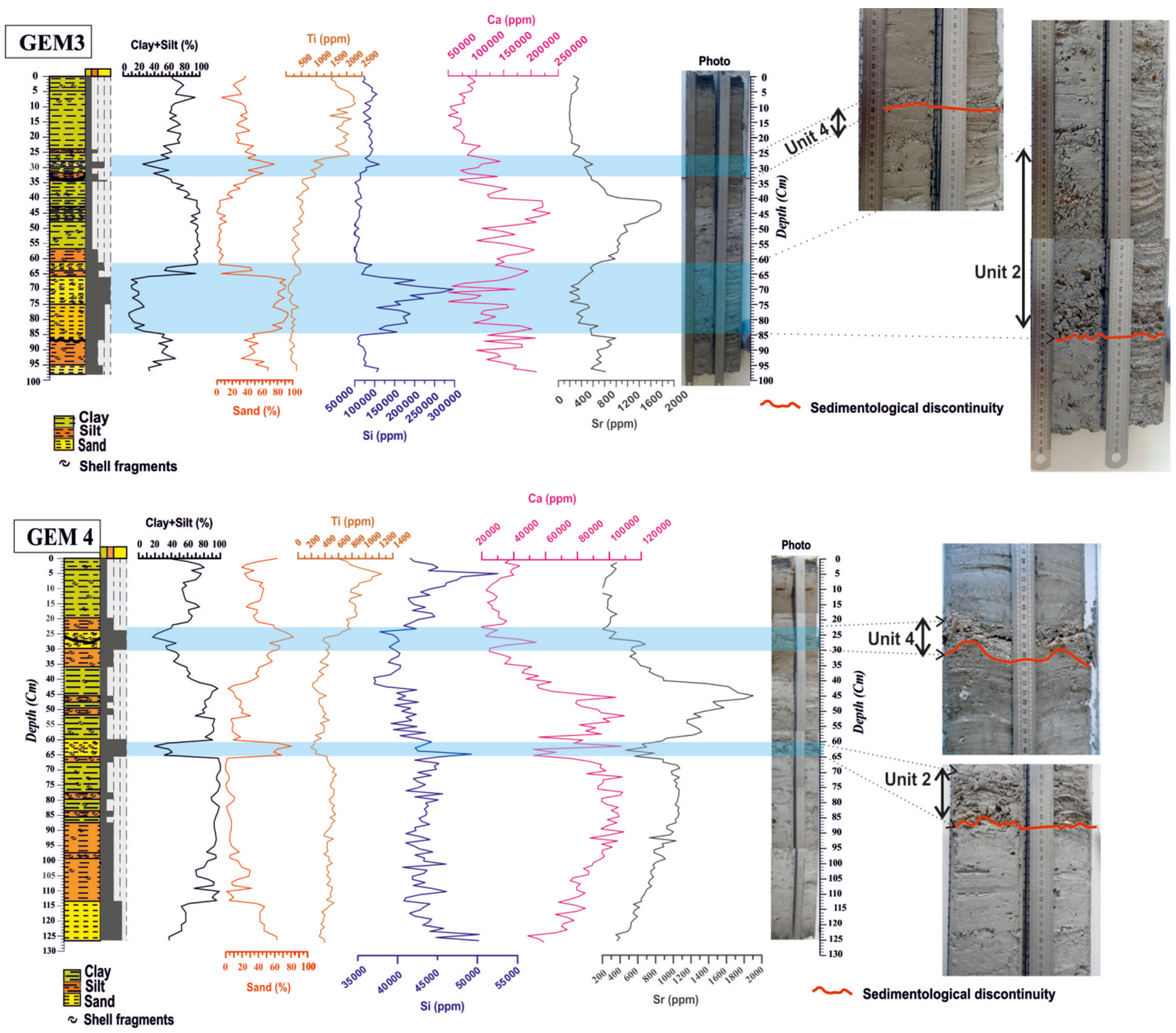

Figure 2. Stratigraphic log and grain size results of GEM3 and GEM4 cores compared to the results obtained from the XRF records (titanium, silicon, calcium, and strontium) vs. depth.

a very thin fine sand. For GEM3, the transition between unit 1 and unit 2 is defined by a sharp contact (Fig. 2).

- The second unit (2), situated between $85-63 \mathrm{~cm}$ in GEM3 and between $66-60 \mathrm{~cm}$ in GEM4, is typically composed of a light-gray sand with a combination of shell fragments and siliciclastic grains. It is probably related to marine incursion and a washover event during an intense event such as a storm or tsunami.

- The third unit (3), situated between 60-36 $\mathrm{cm}$ in GEM3 and between $63-30 \mathrm{~cm}$ in GEM4, is composed mainly of gray silt and shells. In fact, the transition between this unit and the subjacent unit is defined by a discontinuity contact (Fig. 2).
- The fourth unit (4), is about $10 \mathrm{~cm}$ thick in GEM3 and $6 \mathrm{~cm}$ in GEM4. This coarse layer is constituted by a mixture of shell debris and siliciclastic sand. This sand layer is usually characterized by coarse sediments with light colors and also dominated by shell fragments. This coarse-grain-size layer intercalated in the mud sediments indicates an "energetic" event, relative to the background sedimentation. It is probably also linked to a washover event and marine incursion during an intense event such as a storm or tsunami.

- The fifth unit (5) presents a thickness of $26 \mathrm{~cm}$ (GEM3) and $24 \mathrm{~cm}$ (GEM4) and is marked by a massive gray to 

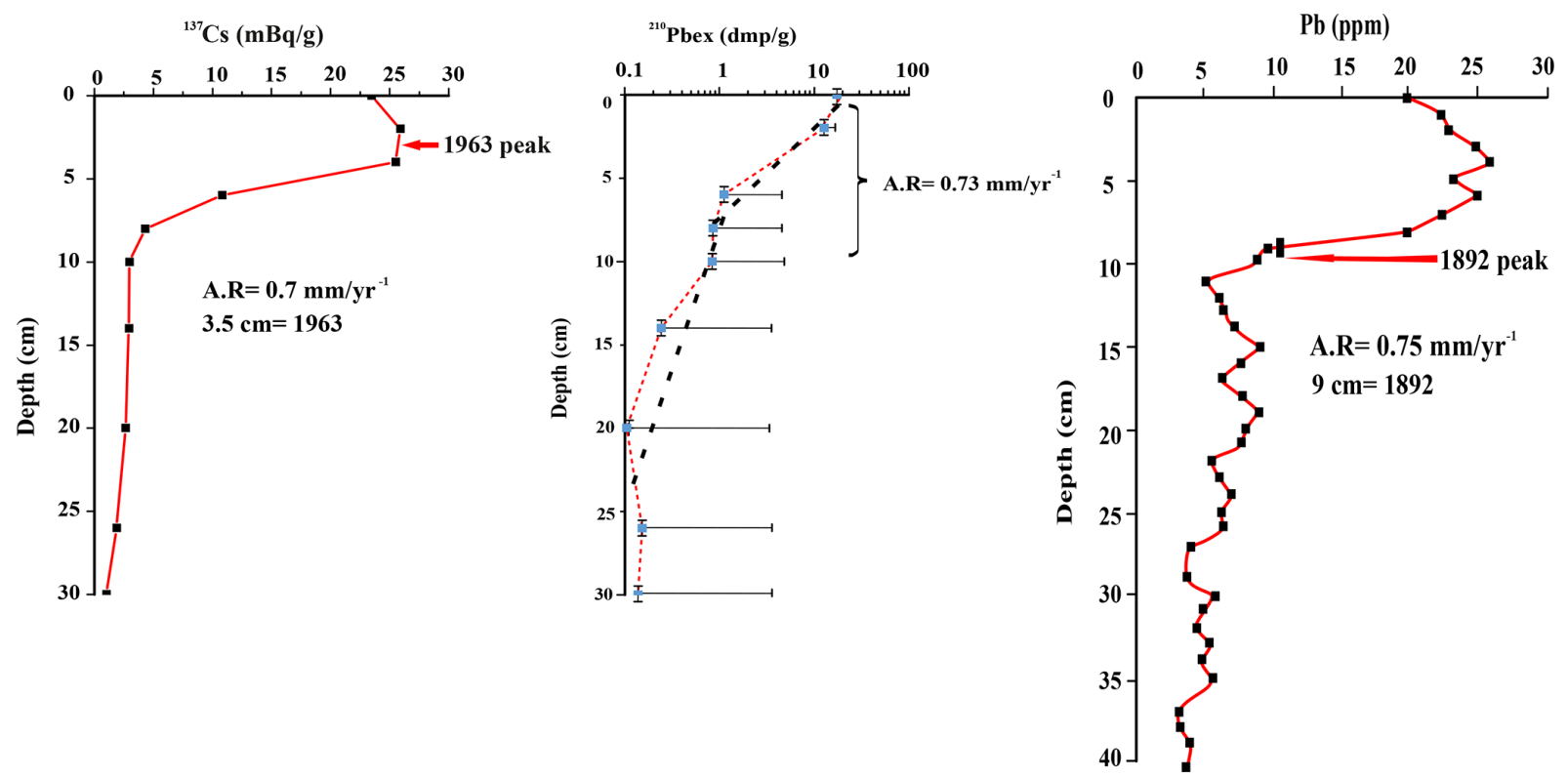

Figure 3. Distribution profile of ${ }^{210} \mathrm{~Pb}$ ex, $\mathrm{Pb}$, and ${ }^{137} \mathrm{Cs}$ vs. depth in GEM3. The ${ }^{210} \mathrm{~Pb}$ data determine a sedimentation rate of $0.73 \mathrm{~mm}$ yr ${ }^{-1}$. The activity depth profile $\mathrm{Cs}$ presents a peak at $3.5 \mathrm{~cm}$, indicating accumulation rates of $0.7 \mathrm{~mm} \mathrm{yr}^{-1}$ for the 1963 depths.

dark clay with a trace of oxidized plant roots in the last $3 \mathrm{~cm}$.

The granulometric analysis shows that the silty clay is the most abundant fraction in our sediment cores (Fig. 2). However, sand is dominant at two levels. The first layer is observed between 86 and $64 \mathrm{~cm}$ in GEM3 and between 60 and $65 \mathrm{~cm}$ in GEM4, whereas the second one is between 35 and $26 \mathrm{~cm}$ in GEM3 and from 30 to $24 \mathrm{~cm}$ in GEM4. These two layers are characterized by the dominance of a sandy quartz material and shell fragments.

The geochemical analysis of GEM3 and GEM4 cores performed using an XRF core scanner has detected 21 chemical elements above the limit of detection. Among these elements, we choose to represent in Fig. 2 only those with a significant downcore variation, which are $\mathrm{Si}, \mathrm{Ca}, \mathrm{Sr}$, and $\mathrm{Ti}$. The silicon represents the marine geochemical pole, while titanium represents the terrigenous one. According to the granulometric and geochemical results of surface samples, the Ti is associated with the silt-clay fraction, whereas the " $\mathrm{Si}$ " is associated with the sandy fraction. Furthermore, the highest $\mathrm{Sr}$ and $\mathrm{Ca}$ values in the two cores are found to be related to the silt-clay fraction between 62 and $33 \mathrm{~cm}$ in GEM3 and between 60 and $30 \mathrm{~cm}$ in GEM4.

\subsubsection{Age model}

The chronology of the GEM3 and GEM4 cores has been established using the ${ }^{14} \mathrm{C}$ dates and also the ${ }^{137} \mathrm{Cs}$ and ${ }^{210} \mathrm{~Pb}$ measurements on monospecific mollusk shell samples and bulk sediments, respectively. In the uppermost $30 \mathrm{~cm}$ of the two cores, the measured ${ }^{210} \mathrm{~Pb}_{\mathrm{ex}}$ values range in GEM3 from
287.47 to $2.29 \mathrm{dmp} \mathrm{g}^{-1}$ (disintegrations per minute per gram) and in GEM4 from 253.67 to $1.01 \mathrm{dmp} \mathrm{g}^{-1}$. In general, the downcore distribution of ${ }^{210} \mathrm{~Pb}$ excess values follows a relatively exponential decrease with depth. Therefore a constant flux, constant supply CF: CS sedimentation model was applied by Goldberg (1963) and Krishnaswamy et al. (1971). The indicated sedimentation rate is about $0.7 \mathrm{~mm} \mathrm{yr}^{-1}$ for GEM3 and $0.6 \mathrm{~mm} \mathrm{yr}^{-1}$ for GEM4. The distribution profile of ${ }^{137} \mathrm{Cs}$ activity shows for the first $10 \mathrm{~cm}$ (Fig. 3) a maximum value at $3.5 \mathrm{~cm}$ in GEM 3 and $3 \mathrm{~cm}$ in GEM4. This can represent the period of the utmost radionuclide fallout in the Northern Hemisphere, which was related to the peak atomic weapons testing in 1963 . The ${ }^{137} \mathrm{Cs}$-obtained sedimentation rate is about $\sim 0.7 \mathrm{~mm} \mathrm{yr}^{-1}$ for GEM3, which is slightly higher than that obtained for GEM4 $\left(0.6 \mathrm{~mm} \mathrm{yr}^{-1}\right.$; Fig. 4). The distribution profile of the total $\mathrm{Pb}$ shows that the beginning of the industrial pollution in 1892 (Latour, 2019) is situated at $9 \mathrm{~cm}$, indicating a sedimentation rate of about $0.75 \mathrm{~mm} \mathrm{yr}^{-1}$ for both cores (Fig. 4). Thereby, sedimentation rate of the GEM3 core calculated using the ${ }^{137} \mathrm{Cs},{ }^{210} \mathrm{~Pb}$, and total $\mathrm{Pb}$ show similar values around $0.75 \mathrm{~mm} \mathrm{yr}^{-1}$, which are slightly higher than that for GEM4 (mean value of around of $\sim 0.6 \mathrm{~mm} \mathrm{yr}^{-1}$ ). The conventional accelerator mass spectrometry (AMS) ${ }^{14} \mathrm{C}$ measurements were performed using mollusk shells (Cerastoderma glaucum) on eight control points for GEM3 (Table 1) and seven for GEM4 (Table 2). Taking into account both the radiocarbon and ${ }^{210} \mathrm{~Pb}_{\mathrm{ex}}$ dates, the local ${ }^{14} \mathrm{C}$ reservoir age in the Ghar El Meleh lagoon was determined. According to the method of Sabatier et al. (2010), the evaluation of the modern ${ }^{14} \mathrm{C}$ reservoir age was conducted by comparing an age obtained from ${ }^{137} \mathrm{Cs}$ 

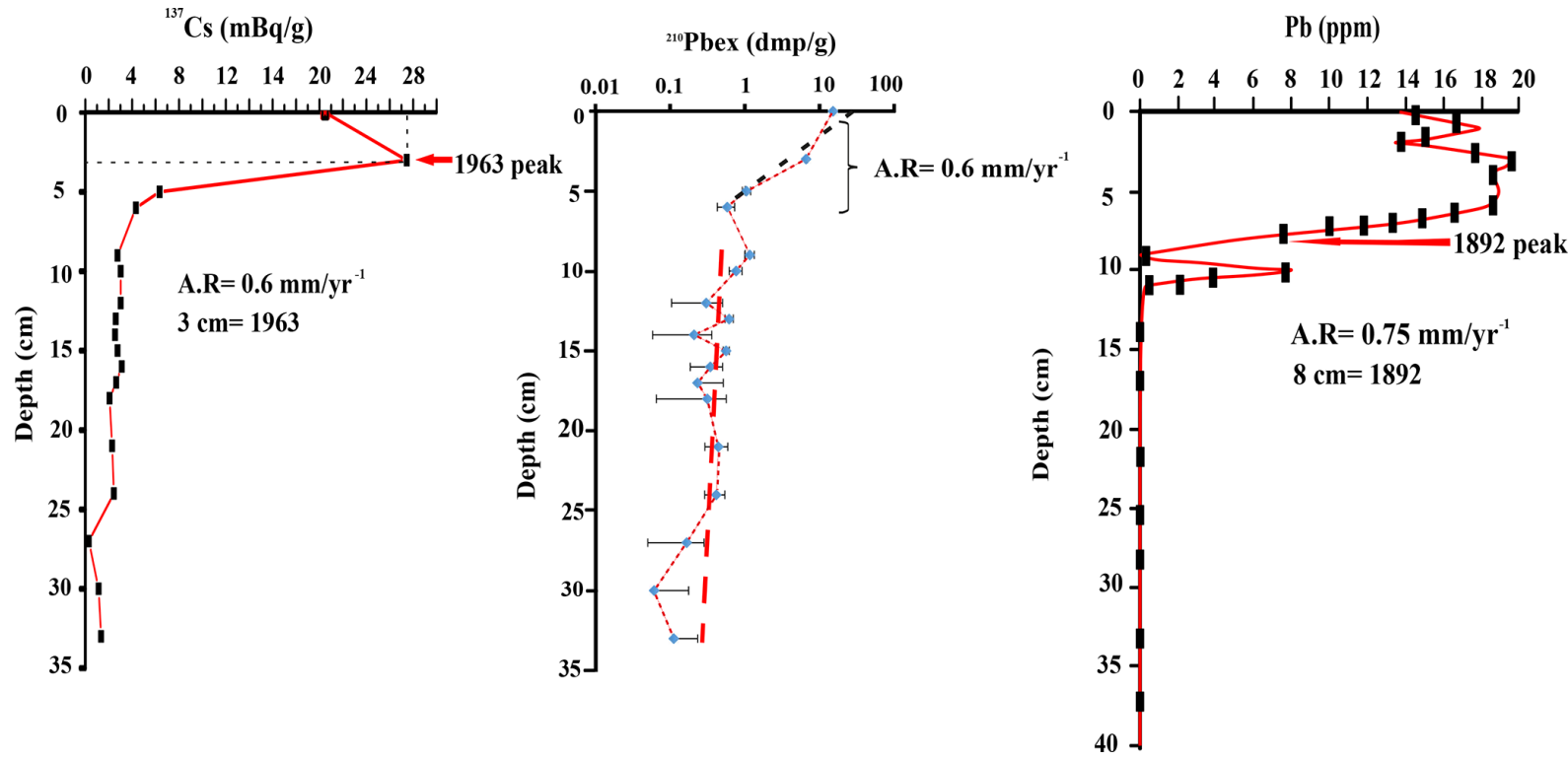

Figure 4. Distribution profile of ${ }^{210} \mathrm{~Pb}_{\mathrm{ex}}, \mathrm{Pb}$, and ${ }^{137} \mathrm{Cs}$ vs. depth in GEM4. The ${ }^{210} \mathrm{~Pb}$ data present a sedimentation rate of $0.6 \mathrm{~mm}$ yr ${ }^{-1}$. The activity depth profile $\mathrm{Cs}$ indicates a peak at $3 \mathrm{~cm}$, determining accumulation rates of $0.6 \mathrm{~mm} \mathrm{yr}^{-1}$ for the 1963 depths.

Table 1. ${ }^{14} \mathrm{C}$ data for shells from GEM3. The model ages were determined by $\mathrm{OxCal}$. The ${ }^{14} \mathrm{C}$ ages are calculated and calibrated using the curve of Marine13 calibration with reservoir age.

\begin{tabular}{|c|c|c|c|c|c|}
\hline Lab code & Mollusk used & $\begin{array}{l}\text { Depth } \\
(\mathrm{cm})\end{array}$ & $\begin{array}{r}\delta^{13} \mathrm{C} \\
(\% o)\end{array}$ & $\begin{array}{r}{ }^{14} \mathrm{C} \text { ages } \\
(\mathrm{BP})\end{array}$ & $\begin{array}{l}{ }^{14} \mathrm{C} \text { ages }(\mathrm{cal} \mathrm{CE}) \\
(1 \sigma \text { ranges }) \\
{[\text { start, end }]}\end{array}$ \\
\hline SacA 42679 & Cerastoderma glaucum & 42 & -0.8 & $565 \pm 30$ & [1692 cal CE, $1765 \mathrm{cal} \mathrm{CE}]$ \\
\hline SacA 42685 & Cerastoderma glaucum & 54 & 1.5 & $930 \pm 30$ & [1399 cal CE, $1451 \mathrm{cal} \mathrm{CE}]$ \\
\hline SacA 42683 & Cerastoderma glaucum & 60 & 0.2 & $1195 \pm 3$ & [1186 cal CE, $1260 \mathrm{cal}]$ \\
\hline SacA 42681 & Cerastoderma glaucum & 70 & 0.2 & $1535 \pm 30$ & [811 cal CE, $902 \mathrm{cal} \mathrm{CE}]$ \\
\hline SacA 42680 & Cerastoderma glaucum & 76 & 1.4 & $1830 \pm 30$ & [550 cal CE, $630 \mathrm{cal} \mathrm{CE}]$ \\
\hline SacA 42686 & Cerastoderma glaucum & 80 & 0.6 & $2015 \pm 30$ & [332 cal CE, $424 \mathrm{cal} \mathrm{CE}]$ \\
\hline SacA 42684 & Cerastoderma glaucum & 88 & -1.1 & $2350 \pm 30$ & [67 cal BCE, $33 \mathrm{cal} \mathrm{CE}]$ \\
\hline SacA 42682 & Cerastoderma glaucum & 93 & -1.4 & $2490 \pm 30$ & [267 cal BCE, $144 \mathrm{cal} \mathrm{BCE}]$ \\
\hline
\end{tabular}

Table 2. ${ }^{14} \mathrm{C}$ data for shells from GEM4. The model ages were determined by $\mathrm{OxCal}$. The ${ }^{14} \mathrm{C}$ ages are calculated and calibrated using the curve of Marine13 calibration with reservoir age.

\begin{tabular}{|c|c|c|c|c|c|}
\hline Lab code & Mollusk used & $\begin{array}{r}\text { Depth } \\
(\mathrm{cm})\end{array}$ & $\begin{array}{r}\delta^{13} \mathrm{C} \\
(\% \circ)\end{array}$ & $\begin{array}{r}{ }^{14} \mathrm{C} \text { ages } \\
\text { (BP) }\end{array}$ & $\begin{array}{l}{ }^{14} \mathrm{C} \text { ages }(\mathrm{cal} \mathrm{CE}) \\
(1 \sigma \text { ranges }) \\
{[\text { start, end] }}\end{array}$ \\
\hline SacA 42676 & Cerastoderma glaucum & 40 & -3.7 & $490 \pm 30$ & [1807 cal CE, $1906 \mathrm{cal} \mathrm{CE}]$ \\
\hline SacA 42675 & Cerastoderma glaucum & 45 & 1.8 & $615 \pm 30$ & [1652 cal CE, $1712 \mathrm{cal} \mathrm{CE}]$ \\
\hline SacA 42673 & Cerastoderma glaucum & 55 & 0.3 & $1181 \pm 30$ & [786 cal CE, $1344 \mathrm{cal} \mathrm{CE}]$ \\
\hline SacA 42672 & Cerastoderma glaucum & 72 & -2.9 & $2545 \pm 30$ & [332 cal BCE, $225 \mathrm{cal}$ BCE] \\
\hline SacA 42674 & Cerastoderma glaucum & 85 & -4.3 & $2660 \pm 30$ & [431 cal BCE, $353 \mathrm{cal} \mathrm{BCE}]$ \\
\hline SacA 42678 & Cerastoderma glaucum & 101 & -6.6 & $2625 \pm 30$ & [399 cal BCE, $339 \mathrm{cal} \mathrm{BCE}]^{*}$ \\
\hline SacA 42677 & Cerastoderma glaucum & 110 & -4.8 & $2725 \pm 30$ & [512 cal BCE, $400 \mathrm{cal} \mathrm{BCE}]$ \\
\hline
\end{tabular}

* Age inversion 
Table 3. ${ }^{14} \mathrm{C}$ age of recent pre-bomb mollusk samples in GEM4 core. The reservoir age $R(t)$ and $\Delta R$ were calculated using the ${ }^{210} \mathrm{~Pb}$ ex date.

\begin{tabular}{|c|c|c|c|c|c|c|}
\hline Lab code & $\begin{array}{l}{ }^{210} \mathrm{~Pb} \\
\text { age } \\
(\mathrm{CE})\end{array}$ & $\begin{array}{l}{ }^{14} \mathrm{C} \\
\text { year } \\
(\mathrm{BP})\end{array}$ & $\begin{array}{c}\text { Tree ring } \\
{ }^{14} \mathrm{C} \text { age }(\mathrm{BP}) \\
\text { IntCall13 }\end{array}$ & $\begin{array}{l}\text { Reservoir } \\
\text { age } R(t) \\
\quad(\mathrm{yr})\end{array}$ & $\begin{array}{l}\text { Model age } \\
\text { (Marine4 } \\
\text { curve) }\end{array}$ & $\begin{array}{l}\Delta R \\
(\mathrm{yr})\end{array}$ \\
\hline SacA 44506 & 1845 & $450 \pm 30$ & $114 \pm 8$ & 336 & $488 \pm 23$ & -38 \\
\hline
\end{tabular}

and ${ }^{210} \mathrm{~Pb}$ data and from geochemical analysis of miningcontaminated lagoonal sediments with an AMS ${ }^{14} \mathrm{C}$ age of a pre-bomb mollusk shell.

According to Reimer et al. (2013), the sea surface reservoir age $R(t)$ for the recent shell (Sac A44506) was measured by subtracting the atmospheric ${ }^{14} \mathrm{C}$ value determined for the historical date $1845 \mathrm{CE}\left(114 \pm 8{ }^{14} \mathrm{C}\right.$ years) from the measured apparent ${ }^{14} \mathrm{C}$ ages of the shell $\left(450 \pm 30{ }^{14} \mathrm{C}\right.$ years; Table 3$)$. This determines an $R(t)$ value of 363 years. The deviance from the total mean reservoir age $(\Delta R)$ is then calculated by subtracting the marine age model value obtained for $1845 \mathrm{CE}$ $\left(488 \pm 23{ }^{14} \mathrm{C}\right.$ years) from the measured apparent ${ }^{14} \mathrm{C}$ age of the mollusk $\left(450 \pm 30{ }^{14} \mathrm{C}\right.$ years; Table 3$)$. The calculated $\Delta R$ around -38 years (Table 3 ) is thus adopted. Finally, the age model of GEM3 and GEM4 cores was established by using $\mathrm{OxCal} 4$ on ${ }^{14} \mathrm{C}$ ages and ${ }^{210} \mathrm{~Pb}_{\mathrm{ex}}$ and ${ }^{137} \mathrm{Cs}$ average sedimentation rates. The ${ }^{14} \mathrm{C}$ mean sedimentation rate calculated is then about $\sim 2.5 \mathrm{~mm} \mathrm{yr}^{-1}$ (Fig. 5a).

As GEM4 indicates a level of erosion or inactive deposition process named "a condensed area" observed from 59 to $72 \mathrm{~cm}$ (between 0 and $1000 \mathrm{cal} \mathrm{CE}$ ), which would instigate an error in the obtained age model (Fig. 5b), the discussion is focused only on the ages estimated from the GEM3 core. For the GEM4 core, the age correction has been obtained by the correlation between the strontium profile of the two cores GEM3 and GEM4. The age models take into account the depth and the thickness of every event deposit.

\subsection{Characterization of different detrital surface sources}

The sedimentation in the lagoon of Ghar El Meleh is manifested by marine and terrestrial inputs. The geographic distribution (Fig. 6) of granulometric results indicates that the high percentage of coarse sediments (sands $>75 \%$ ) are from the sandy barrier, whereas sediments of the Medjerda watershed are distinguished by a very high percentage of fine sediments (silt and clay). The Medjerda River and the affluent around it constitute the main origins of fine fractions (clay and silt) in the Ghar El Meleh lagoon. The mapping of terrigenous elements such as silicon, titanium, and iron contents in surface sediments confirms this distinction of detrital origins around the Ghar El Meleh lagoon. High Si values (> 110000 ppm) especially distinguish the sandy barrier. Moreover, the highest contents of $\mathrm{Ti}(>1400 \mathrm{ppm})$ and $\mathrm{Fe}(>17500 \mathrm{ppm})$ are retrieved in sediment from the watershed of the Medjerda (Fig. 7a). To make our interpretations more vigorous, a tree diagram was generated using the statistical program XLSTAT 2021, which is used as an additional tool to identify and test the statistical link between all the elements and the deposits using both sedimentological data and XRF data of surface sediments in the study area (Fig. 7b). In the first cluster, the association of the coarse fraction (sand) with the $\mathrm{Si}$ is clear, suggesting that the silicone is coming from coarse marine sand inputs. However, the second cluster determines an assembly between the terrigenous elements ( $\mathrm{Ti}, \mathrm{Fe}, \mathrm{Sr}$, and $\mathrm{Ca}$ ) and fine fractions (silt and sand). This difference in the origin of the terrigenous inputs in Ghar El Meleh lagoon is explained by the fact that, during flood events, finer sediments are coming from the Medjerda watershed, whereas, at the time of marine storms, coarse marine sand inputs are from the barrier.

In coastal environments, the principal component analysis (PCA) was usually performed on the sediment sampled around lagoons in order to characterize the different sources of sediments deposited in the lagoon (Degeai et al., 2015; Gaceur et al., 2017; Affouri et al., 2017; Khalfaoui et al., 2019) and to determine the several end-members related to potential sediment source supplies (Fig. 8). We choose the $\mathrm{Mn}, \mathrm{Ti}, \mathrm{Zn}, \mathrm{Ba}, \mathrm{Rb}, \mathrm{Fe}, \mathrm{Sr}, \mathrm{Ca}$, and $\mathrm{Si}$ elements due to their good detection by the mobile XRF. We established the calculation factors $\mathrm{F} 161.12 \%$ and $\mathrm{F} 211.13 \%$ of the geochemical dataset using the XLSTAT-2016 statistical software. The two first factorial factors represented in the PCA diagram present (Fig. 8) $72.25 \%$ of the entire variance in the dataset. Factor 1 accounts for $61.12 \%$ of the entire variance. Factor 1 is marked by a positive loading for terrigenous elements $\mathrm{Rb}, \mathrm{Ti}, \mathrm{Ba}, \mathrm{Mn}, \mathrm{Fe}$, and $\mathrm{Zn}$, whereas the $\mathrm{Ca}$ and $\mathrm{Sr}$ present a modest positive loading and are inserted in factor 1 . Factor 2 represents $11.13 \%$ of the global variance. It indicates positive loading for $\mathrm{Si}, \mathrm{Mn}, \mathrm{Ti}, \mathrm{Ba}, \mathrm{Zn}, \mathrm{Rb}$, and $\mathrm{Fe}$, whereas $\mathrm{Sr}$ and $\mathrm{Ca}$ have negative loadings.

The geochemical results of the downcore sediments (CEM3 and CEM4) show the variation in the concentration of chemical elements such as $\mathrm{Fe}, \mathrm{Ti}, \mathrm{Ca}$, $\mathrm{Sr}$, and $\mathrm{Si}$. The PCA of the two cores shows the presence of three well-differentiated poles (Fig. 8). The F1 and F2 statistical variables reveal a good correlation between the elements present in the same pole (89\% for GEM3 and $79 \%$ for GEM4). 


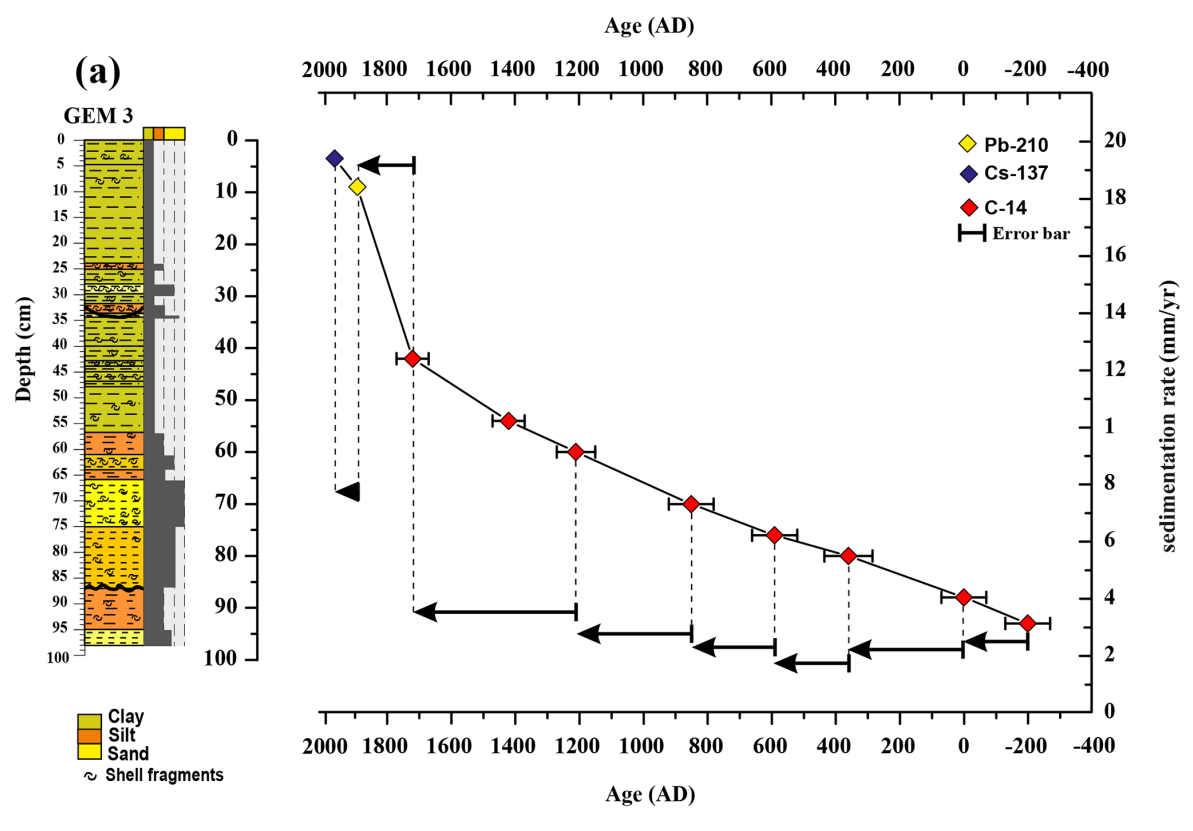

(b)

Age (AD)

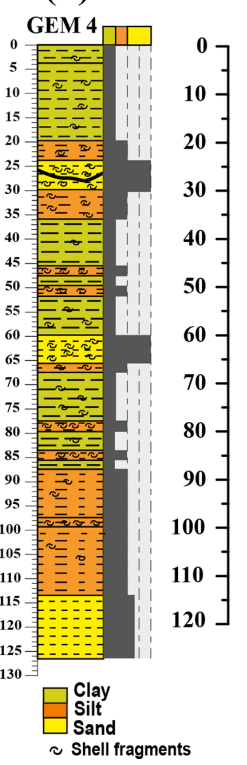

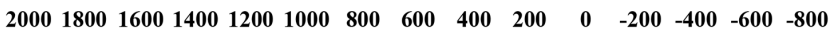
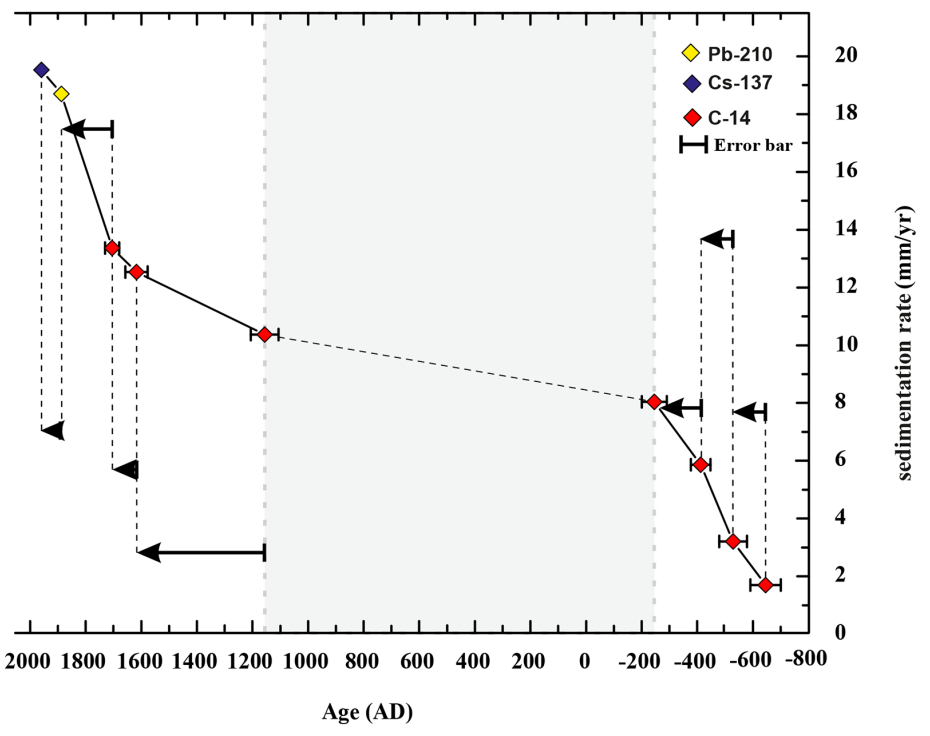

Figure 5. (a) Sediment age-depth for the core GEM3 sampled from Ghar El Meleh lagoon (arrows: sedimentation rate variation). OxCal 4.3 has been used to calculate the age model with eight samples for ${ }^{14} \mathrm{C}$ dates and only one sample for $\mathrm{Pb}$ and $\mathrm{Cs}$ dates. (b) Sediment age-depth for the core GEM3 sampled from Ghar El Meleh lagoon (arrows: sedimentation rate variation). OxCal 4.3 has been used to calculate the age model with seven samples for ${ }^{14} \mathrm{C}$ dates and only one sample for $\mathrm{Pb}$ and $\mathrm{Cs}$ dates. The blue band determines a period of inactive deposition process or erosion of so-called "a condensed area".

Based on these statistical analyses of all geochemical data (surface sediments and cores), three distinct sources of sediments were identified (Fig. 8): (i) terrigenous or alluvial sources (Mn, Fe, $\mathrm{Zn}, \mathrm{Ba}, \mathrm{Rb}$ ) mainly discharged by rivers during floods, (ii) marine source ( $\mathrm{Si}$ ) such as sands coming from the sandy coastal barrier during marine submersion, (iii) and $\mathrm{Sr}$ and $\mathrm{Ca}$ as autogenic and/or biogenic origins linked to the precipitation of minerals or the dissolution of some shells. 
(a)

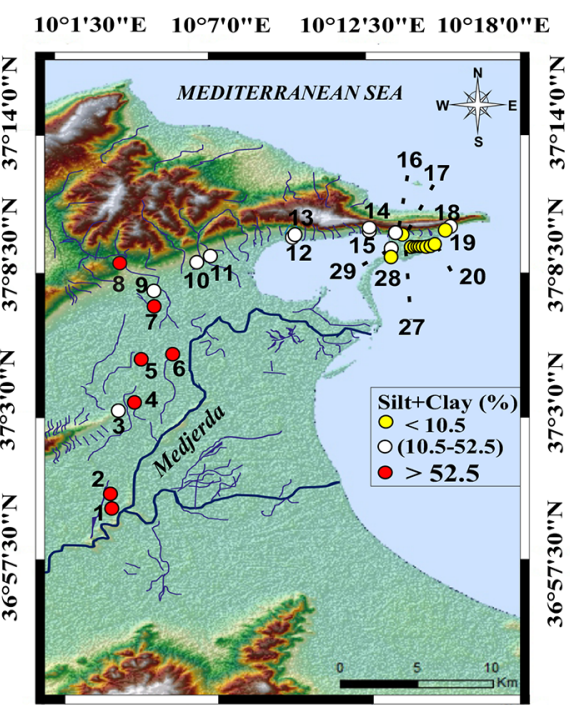

$10^{\circ} 10^{\prime \prime}$ E $10^{\circ} 7^{\prime} 0^{\prime \prime}$ E $10^{\circ} 12^{\prime} 30^{\prime \prime}$ E $10^{\circ} 18^{\prime} 0^{\prime \prime} \mathrm{E}$

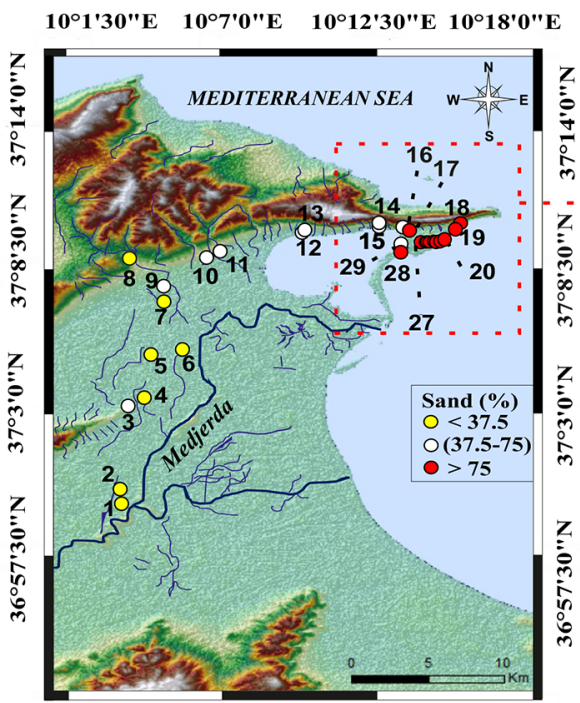

$10^{\circ} 10^{\prime \prime E} \quad 1^{\circ} 7^{\prime} 0^{\prime \prime E} \quad 10^{\circ} 12^{\prime} 30^{\prime \prime E} \quad 1^{\circ} 18^{\prime} 0 " \mathrm{E}$
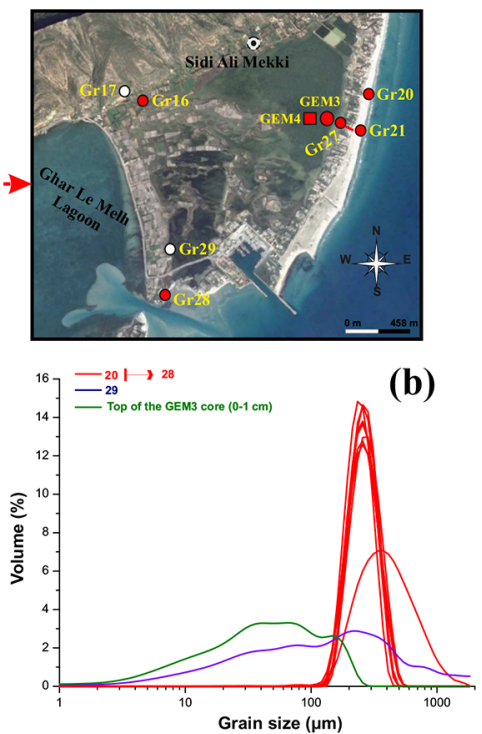

Figure 6. (a) Topographic maps of the sand, silt, and clay percentage distributed in the Medjerda watershed and around the lagoon of Ghar El Meleh (created by Radewane Hout using ArcGIS). (b) Topographic map of the two cores and the different sediment samples collected from Ghar El Meleh lagoon and its surroundings (e.g., (C) Google Earth). (c) Particle size distributions $(\phi<2000 \mu \mathrm{m})$ of representative samples around the Ghar El Meleh lagoon.

(a)
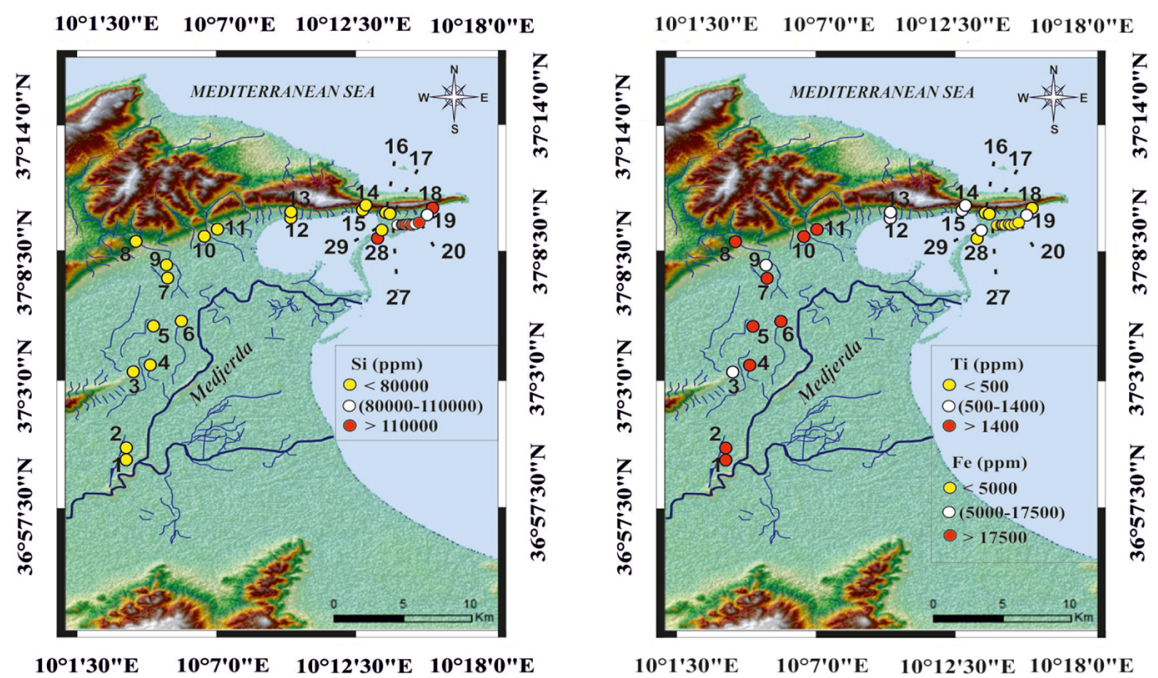

(b)

$10^{\circ} 10^{\prime}=10^{\circ} 7^{\prime} 0 " \mathrm{E} \quad 10^{\circ} 12^{\prime} 30^{\prime \prime} \mathrm{E} \quad 10^{\circ} 18^{\prime} 0 " \mathrm{E}$

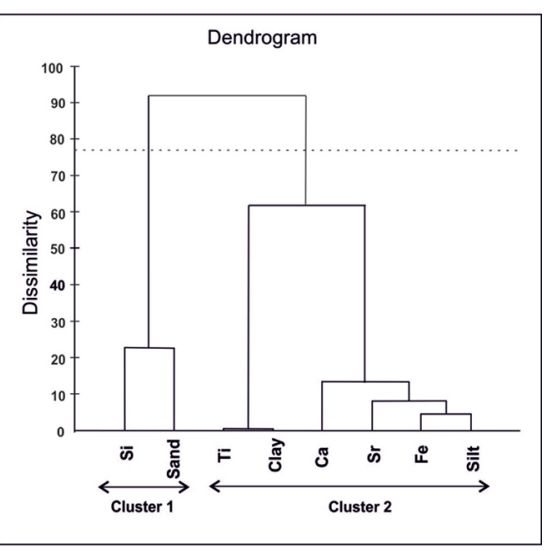

Figure 7. (a) Topographic maps of the iron ( $\mathrm{Fe}$ ), titanium (Ti), and silicon ( $\mathrm{Si}$ ) contents in the coastal plain of the Medjerda and around Ghar El Meleh lagoon (created by Radewane Hout using ArcGIS). (b) Cluster analysis of surface sediments around Ghar El Meleh lagoon.

\section{Discussion}

\subsection{Site sensitivity to overwash deposits}

The sensitivity of the site to the overwash deposits can result from several factors such as barrier elevation, sediment supply, inlet, and a change in sea level (Donnelly et al., 2004; Scileppi and Donnelly, 2007; Dezileau et al., 2016). Gen- erally, an increase in sea level causes the barrier to move landward. Thus, the highest number of sand layers in a sediment core can be the consequence of a simple sea-level change. In the Mediterranean Sea and especially during the last 5000 years, the sea level has stayed more or less stable (<2 m, Pirazzoli, 1991; Lambeck and Bard, 2000). 
Surface sediments

Variables (axes F1 and F2: $72.25 \%$ )

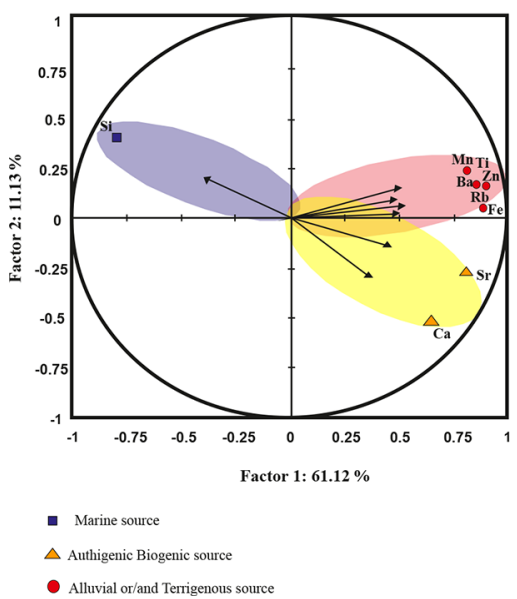

GEM3

Variables (axes F1 and F2: $88.97 \%$ )

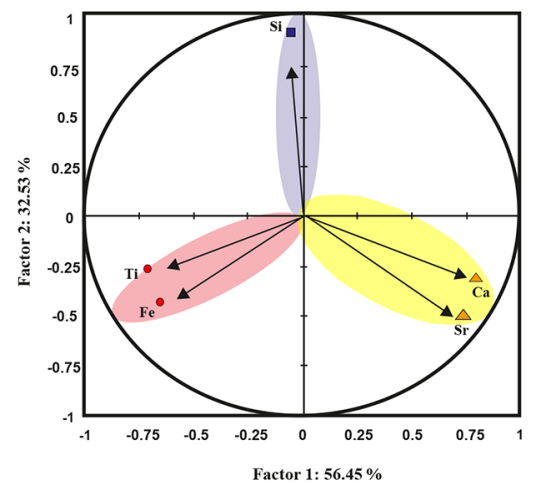

GEM4

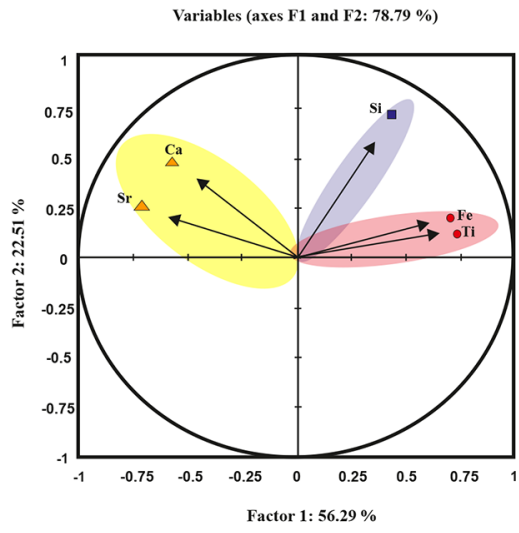

Figure 8. The different surface sediment sources from the Medjerda watershed and Ghar El Meleh lagoon obtained by using the statistic model as the principal component analysis (PCA).

Studies concerning Holocene sea-level fluctuations along the Tunisian coast have suggested a stabilization in relative sea level during the last 6000 years (Jedoui et al., 1998), which is very small and probably not enough to completely change the deposition environment of the Ghar El Meleh lagoon. Furthermore, sedimentation in the two cores started 2500 years ago; in this short period, the influence of the seal level change has not drastically affected sedimentation in the center of the lagoon.

Cores GEM3 and GEM4 present generally a sedimentary sequence dominated by fine-grained sediments (clay and silt), suggesting that the lagoon of Ghar El Meleh has succeeded in keeping a low-energy environment during the last 2500 years.

The proxies applied in this work (granulometry and geochemistry) as well as the sedimentary indicators (discontinuity contact) showed that all sandy coarse peaks present within the GEM3 and the GEM4 cores were deposited through marine high-energy events and not by a gradual change in sea level.

The presence of a nearby inlet may increase the sensitivity of a particular area to storm-induced deposition. It allows for a lesser storm with a lower wave surge to more easily penetrate and transport coarse sediment into the back-barrier area. If a large inlet had existed over a long period and had provided a ready conduit for sand from the Gulf of Tunis to the Ghar El Meleh lagoon, this would have been reflected in the cores (deposition of thick sand layer over a long period of time). However, no evidence of such active tidal connection lasting a long time is found in sedimentological and geochemical data for the past 2500 years.

Granulometric and geochemical observations of the GEM3 and the GEM4 cores show a sedimentary sequence dominated by silty-clay deposits and interrupted over time by some allochthonous coarse materials. To determine the source of these sandy layers, we compared their geochemical attributes with those from surface samples. This allowed us to establish whether these deposits had a continental (river floods) or marine origin (storms and tsunamis). The two sand deposits present in the GEM3 and GEM4 cores have a geochemical correlation with marine coastal surface samples; both show enrichment with $\mathrm{Si}$ and depletion with $\mathrm{Fe}$ and $\mathrm{Ti}$, which reveals a marine source for these high-energy deposits. The results demonstrate that Ghar El Meleh lagoon has been confronted with different episodes of marine submersion during the last 2500 years. In this respect, the lagoonal deposit of Ghar El Meleh can provide valuable information on these aspects of the past and subsequently provide a forecast about the future. So we can suggest that the Tunisian coast is very sensitive to extreme events; these coastal areas are especially vital for Tunisia's tourism development and economy. In the future, these hazard events can present much destruction and cause significant human and economic losses. In light of this fact, much risk management should be taken into consideration and applied by the governorate. A regional risk assessment methodology must be developed for the assessment of the potential impacts of climate change in the Tunisian coastal zone of the Ghar El Meleh lagoon.

\subsection{Extreme events and paleoenvironmental changes}

The Late Holocene lagoonal history of Ghar El Meleh may be divided into five phases that record the connection between the lagoon and the sea in relation to the sandy barrier's evolution. The different phases can be described as follows: 


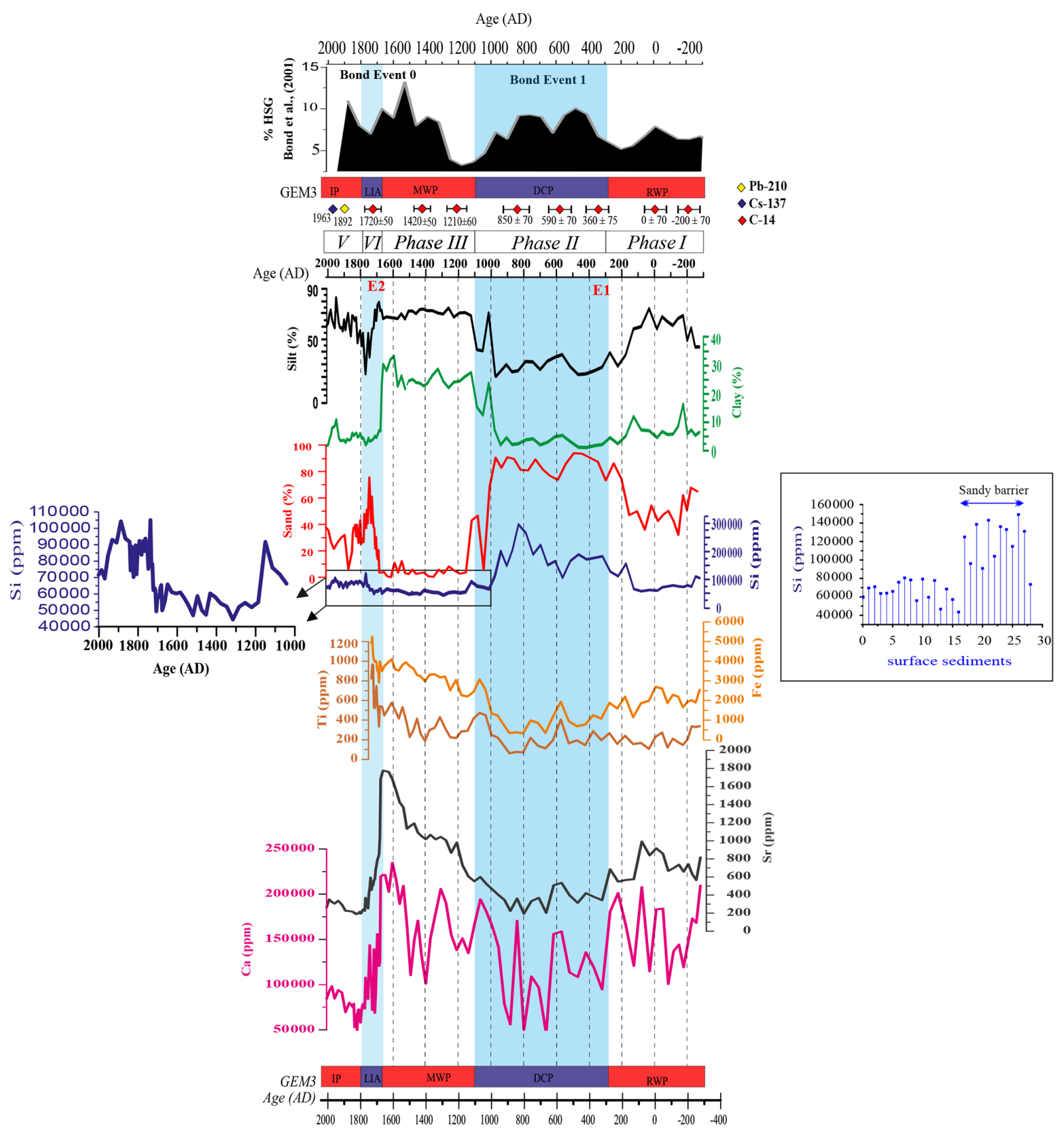

Figure 9. Evolution of grain size population compared to the results obtained from the XRF records (iron, calcium, silicon, titanium, and strontium), vs. age.

- The first phase, dated from -275 to $300 \mathrm{calCE}$, is marked by a high percentage of fine sediments (about $70 \%$ of silt) (Fig. 9). Our geochemical results show a relatively high concentration of terrigenous elements $\mathrm{Ti}$ (around $250 \mathrm{ppm}$ ) and Fe (around $2500 \mathrm{ppm}$ ). This predominance of the fine fraction, rich in $\mathrm{Ti}$ and $\mathrm{Fe}$, means that the lagoon is filled in sediments coming from the Medjerda River. The presence of fine material suggests that the hydrodynamic current in the lagoon is low, and we have a protected lagoon with a well-constructed sandy barrier. This accumulation of fine sediment could also indicate a higher contribution of sediments from the Medjerda River. Indeed, this interval (Roman Climatic Optimum) corresponds to a more humid phase in the north of Tunisia (Stevenson et al., 1993).

- The second phase started around $300 \mathrm{calCE}$ and finished at $1100 \mathrm{cal} \mathrm{CE}$. Our granulometric and geochemical results demonstrate that the sedimentation of Ghar 
El Meleh lagoon during this period was mainly controlled by a marine contribution. This phase is marked by a decrease in the percentage of silt and a rise in the percentage of sand (about $80 \%$ ) as well as the presence of a discontinuity contact with the underlying unit. This time interval also shows the presence of a high amount of silicon ( $\mathrm{Si}>100000$ ppm) (Fig. 9), which stipulates an increase in the sandy material supply. The decrease in the silty-clay fraction $(10 \%)$ can be related to a dilution by high marine inputs. The dominance of coarse sediment, rich in $\mathrm{Si}$, could be explained by a weakening of the sandy barrier due to an increase in storm events. Degeai et al. (2015) and Sabatier et al. (2012) have clearly recorded a period of higher storm activity from 400 to $800 \mathrm{cal} \mathrm{yr} \mathrm{CE}$ in the occidental part of the Mediterranean area. This period, named the Dark Age Cold Period, coincides with the North Atlantic cooling phase known as Bond Event 1 (Bond et al., 2001). Dezileau et al. (2011) and Sabatier et al. (2012) have demonstrated that intervals of an increase in storm activity in the western Mediterranean area seem to be well related to the cold periods of the Holocene. During these cold periods, the sea ice was prolonged over the North Atlantic basin southward, especially during winter (Lamb, 1995). Dezileau et al. (2011, 2016) hypothesized that during the Little Ice Age, the increase in the super-storm activity was probably due to the thermal gradient increase leading to enhanced lower tropospheric baroclinicity over a large central European domain. This mechanism related to a southward movement of the storm track suggests an enhancement in storm activity in the western Mediterranean Sea, in accordance with simulations (Raible et al., 2007). However, this sand deposit may have another origin. Indeed, this deposit was dated at around $332 \pm 30 \mathrm{cal}$ CE. This event E1 coincides with the tsunami event of $365 \mathrm{CE}$. This extreme event was generated by an earthquake of $M_{\mathrm{w}} 8.3$ magnitude (Paris et al., 2020) and is supposed to have been the most powerful ever in the eastern Mediterranean. From numerical modeling, Pararas-Carayannis and Mader (2010) indicate that the $365 \mathrm{CE}$ tsunami heavily affected coastal areas throughout the eastern Mediterranean region: Palestine, South Asia Minor, Cyprus, the Nile Delta, Careen, and Apollonia. In the central part of the Mediterranean region the cities of eastern Sicily, the coastline of Calabria, and Greece were affected (Pararas-Carayannis, 2011). In Tunisia, the recent archeological discovery of the immersed city of Neapolis in the northern Gulf of Hammamet in 2017 suggests the occurrence of a tsunami in 365 CE (Aounallah and Fantar, 2006; INP, 2017). We can thus hypothesize that the sand deposited around 365 cal CE could also be associated with this tsunami event. However, the distinction between the storm and tsunami deposits is still controversial, and several stud- ies have pointed out many hypotheses regarding the diagnostic characteristics of these deposits (Kortekaas and Dawson, 2007; Morton et al., 2007; Tappin, 2007; Engel et al., 2010; Sakuna-Schwartz et al., 2015). Hence, the sedimentary characteristics of tsunamis or storm deposits are very similar (Costa et al., 2015). Nevertheless, Morton et al. (2007) used some sedimentological criteria to distinguish storms from tsunami deposits. For example, the storm-originated deposits present a moderately thick sand bed composed of several sub-horizontal planar laminations organized into multiple laminates. The stratification associated with bed-load transport and abundant shell fragments organized in laminations also favors a storm origin. In contrast, the presence of internal mud laminae or mud intraclasts is stronger evidence of tsunami deposits. However, in our case, the sand bed that corresponds to the extreme event is characterized by a single homogeneous bed (6-9 cm thick) with no evident sedimentary structures (such as laminations) that correspond to either storm or tsunami deposits. To determine the origin of our thin coarse layer more precisely, we explored the regional historical storm's records and tsunamis data.

- The third phase, dated from 1100 to $1690 \mathrm{calCE}$, is marked by a decrease in sandy material and an increase in clay material (about 30\%) (Fig. 9). The concentration of terrigenous elements, Ti (around $400 \mathrm{ppm}$ ) and Fe (around $3500 \mathrm{ppm}$ ) (Fig. 9), is high during this period. This kind of sedimentation is typically associated with the processes of decantation in the lagoon (Liu and Fearn, 2000; Donnelly et al., 2004). During this third phase, the lagoon is protected by the sandy barrier. This increase in the silty-clay fraction could also be due to a decrease in storm activity and/or an increase in fine sediments transported into the lagoon by higher runoff of the Medjerda River during the Medieval Warm Period.

- The fourth phase started at $1690 \mathrm{cal} \mathrm{CE}$ and finished at $1760 \mathrm{cal}$ CE. This phase was characterized by a high deposition of sand, about $75 \%$ of the total sediment (Fig. 9), indicating an opening of the lagoon (Fig. 10). The presence of coarse sediments can be explained by a higher marine influence. Interestingly, this coarsegrained layer E2 is recorded in both cores (from 26 to $35 \mathrm{~cm}$ for GEM3 and from 24 to $30 \mathrm{~cm}$ for GEM4) collected at 200 and $400 \mathrm{~m}$ from the sandy barrier, respectively (Fig. 10). Thus, this period could be a sign of an increase in intense storm activity. Indeed, this interval corresponds to the historic period called the "Little Ice Age" (LIA), which coincides with the North Atlantic cooling phase known as Bond Event 0 (Bond et al., 2001). Many studies (Sabatier et al., 2012; Degeai et al., 2015; Dezileau et al., 2016) have clearly recorded a higher storm activity between 1400 and 1800 cal yr CE in the occidental region of the Mediterranean Sea. This 


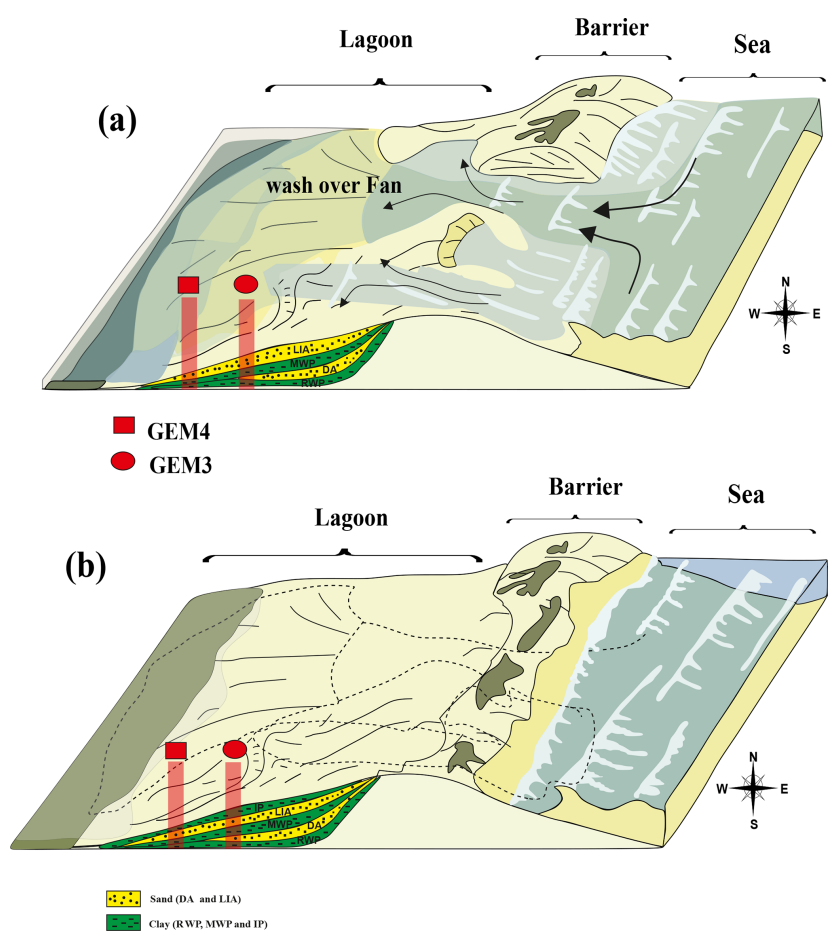

Figure 10. Three-dimensional diagram of the Ghar El Meleh lagoon evolution. (a) Opening of the sandy lido and deposition of the washover in the lagoonal sediment. (b) Reclosure of the lagoon.

sand deposit could also be associated with a tsunami event. This period corresponds to the documented $\mathrm{Si}$ cilian tsunami that occurred in $1693 \mathrm{CE}$. Due to its geographic position, the Ghar El Meleh lagoon may be affected by this 1693 tsunami.

The sedimentary characteristics of tsunami or storm deposits are very similar (Hawkes et al., 2007; Morton et al., 2007; Kortekaas and Dawson, 2007; Mamo et al., 2009). Regarding the diagnostic characteristics of storm or tsunami deposits, several studies have pointed out many hypotheses and determined that their distinctions are very controversial (Tappin, 2007; Engel and Brückner, 2011; Sakuna-Schwartz et al., 2015). Considering the available data on GEM3 and GEM4 sediment cores, the hypothesis of tsunami or storm origin for this recorded extreme event remains open. Deciphering the origin of this event requires further investigations, such a modeling of tsunami wave propagation for example.

The fifth phase, dated from 1760 to 2012 cal CE, is characterized by fine sediments (Fig. 9). This fifth phase shows a protected lagoon (Fig. 10) and suggests that no catastrophic intense sea events have struck Gar El Meleh lagoon during this last phase.

\section{Conclusion}

To identify the paleoextreme events (storms or tsunamis) and to reconstruct the paleoevolution of the lagoon of Ghar El Meleh, in the northeast of Tunisia, high-resolution sedimentological, geochemical, and geochronological analysis was performed. This approach gives information about the paleoenvironmental changes in Ghar El Meleh lagoon and paleoextreme events over the last 2300 years. Five phases and two extreme events have been identified: the first phase (from -275 to $300 \mathrm{cal} \mathrm{CE}$ ) indicates a protected lagoon. The second phase from 300 to 1100 cal CE shows an opening lagoon and more marine inputs. This period may be associated with a storm activity during the Dark Age Cold Period but may also be related to the $356 \mathrm{CE}$ tsunami event E1. The third phase indicates an isolated lagoon and coincides with the Medieval Warm period (from 1100 to $1690 \mathrm{cal} C \mathrm{CE}$ ). The fourth phase presents an opening phase of the lagoon and may be due to an enhancement of storm activity during the Little Ice Age or the occurrence of the 1693 tsunami event mentioned in this study as E2. The fifth phase covered the last 250 years and a reclosing lagoon. Even if our records allowed us to detect past extreme events, it is not possible to differentiate if they are due to tsunamis or storms. Deciphering the origin of these events requires further investigation.

Code availability. The code used in this paper is available at https://doi.org/10.5281/zenodo.5744957 (Kohlia et al., 2021).

Data availability. The survey datasets used in this article are available open-access on Zenodo. Please find the data at https://doi.org/10.5281/zenodo.5744957 (Kohila et al., 2021).

Author contributions. BSK has performed the granulometric and geochemical analyses. BSK prepared the paper with contributions from all co-authors (LD, SB, TM, and NK).

Competing interests. The contact author has declared that neither they nor their co-authors have any competing interests.

Disclaimer. Publisher's note: Copernicus Publications remains neutral with regard to jurisdictional claims in published maps and institutional affiliations.

Special issue statement. This article is part of the special issue "Coastal hazards and hydro-meteorological extremes". It is not associated with a conference. 
Acknowledgements. The authors would like to thank the Paris Saclay University (French Atomic Energy Commission) and especially the Laboratoire de Mesure ${ }^{14} \mathrm{C}$ (LMC14) ARTEMIS at the CEA for the ${ }^{14} \mathrm{C}$ analyses. We are grateful for the projects MISTRALS PALEOMEX, the PHC-UTIQUE no. 14G1002, and the MEDYNA FP7-IRSES 2014-2017 for their financial support. We would also like to thank Radewane Hout for his help in the achievement of some figures.

Financial support. We are grateful to Ministry of Higher Education and Scientific research of Tunisia and "Ecole doctorale Sciences Fondamentales de la Facultée des Sciences de Sfax" for financial support. This work was financially supported by the FrenchTunisian joint project PHC-Utique (Partenariats Hubert Curien no. 14G1002). Financial support was also provided by the MEDYNA FP7-IRSES 2014-2017.

Review statement. This paper was edited by Paolo Tarolli and reviewed by Raphael Paris and two anonymous referees.

\section{References}

Added, A.: Biogeochemical cycles of Org-C, Tot-N and Tot-S in the sediment of the Ghar El Melh Lagoon (north of Tunisia), J. Mar. Syst., 30, 139-154, 2001.

Affouri, A., Dezileau, L., and Kallel, N.: Extreme flood event reconstruction spanning the last century in the El Bibane Lagoon (southeastern Tunisia): a multi-proxy approach, Clim. Past, 13, 711-727, https://doi.org/10.5194/cp-13-711-2017, 2017.

Ahmadun, F. R., Wong, M. M. R., and Mat Said, A.: Consequences of the 2004 Indian Ocean Tsunami in Malaysia, Saf. Sci., 121, 619-631, https://doi.org/10.1016/j.ssci.2019.05.016, 2020.

Álvarez-Gómez, J. A. and Gonzalez, M.: Tsunami hazard at the Western Mediterranean Spanish coast from seismic sources, Nat. Hazards Earth Syst. Sci., 11, 227-240, https://doi.org/10.5194/nhess-11-227-2011, 2011.

Amrouni, O., Hzami, A., and Heggy, E.: Photogrammetric assessment of shoreline retreat in North Africa: Anthropogenic and natural drivers, ISPRS J. Photogram. Remote Sens., 157, 73-92, https://doi.org/10.1016/j.isprsjprs.2019.09.001, 2019.

Aounallah, S. and Fantar, M.: À la découverte du Cap Bon, Guid. Hist. archéologique, Tunis, 2006.

Bond, G., Kromer, B., Beer, J., Muscheler, R., Evans, M. N., Showers, W., Hoffmann, S., Lotti-Bond, R., Hajdas, I., and Bonani, G.: Persistent solar influence on North Atlantic climate during the Holocene, Science, 294, 2130-2136, 2001.

Cardona, O. D: La necesidad de repensar de manera holística los conceptos de vulnerabilidad y riesgo, available at: http://hdl. handle.net/20.500.11762/19852 (last access: 1 December 2021), 2002.

Chaumillon, E., Bertin, X., Fortunato, A. B., Bajo, M., Schneider, J.-L., Dezileau, L., Walsh, J. P., Michelot, A., Chauveau, E., Créach, A., and others: Storm-induced marine flooding: Lessons from a multidisciplinary approach, Earth-Sci. Rev., 165, 151$184,2017$.
Claude, J., Francillon, G., and Loyer, J.-Y.: Les alluvions déposées par l'Oued Medjerda lors de la crue exceptionnelle de mars 1973, Cah. ORSTOM, Hydrol., XIV, 37-109, 1977.

Costa, P. J., Andrade, C., Cascalho, J., Dawson, A. G., Freitas, M. C., Paris, R., and Dawson, S.: Onshore tsunami sediment transport mechanisms inferred from heavy mineral assemblages, Holocene, 25, 795-809, 2015.

Degeai, J. P., Devillers, B., Dezileau, L., Oueslati, H., and Bony, G.: Major storm periods and climate forcing in the Western Mediterranean during the Late Holocene, Quaternary Sci. Rev., 129, 37 56, https://doi.org/10.1016/j.quascirev.2015.10.009, 2015.

Delile, H., Abichou, A., Gadhoum, A., Goiran, J. P., Pleuger, E., Monchambert, J. Y., Wilson, A., Fentress, E., Quinn, J., Ben Jerbania, I., and Ghozzi, F.: The Geoarchaeology Of Utica, Tunisia: The Paleogeography of the Mejerda Delta and Hypotheses Concerning the location of the Ancient Harbor, Geoarchaeology, 30, 291-306, https://doi.org/10.10002/gea.21514, 2015.

Dezileau, L., Sabatier, P., Blanchemanche, P., Joly, B., Swingedouw, D., Cassou, C., Castaings, J., Martinez, P., and Von Grafenstein, U.: Intense storm activity during the Little Ice Age on the French Mediterranean coast, Palaeogeogr. Palaeocl., 299, 289-297, 2011.

Dezileau, L., Pérez-Ruzafa, A., Blanchemanche, P., Degeai, J. P., Raji, O., Martinez, P., Marcos, C., and Von Grafenstein, U.: Extreme storms during the last 6500 years from lagoonal sedimentary archives in the Mar Menor (SE Spain), Clim. Past, 12, 13891400, https://doi.org/10.5194/cp-12-1389-2016, 2016.

Donnelly, J. P., Webb III, T., Murnane, R., and Liu, K.: Backbarrier sedimentary records of intense hurricane landfalls in the northeastern United States, Hurricanes Typhoons Past, Present. Futur., 55, 58-95, 2004.

El Arrim, A.: Etude d'impact de la dynamique sédimentaire e, Diplôme Dr. Spécialité en Géologie, Fac. des Sci., Tunis, p. 208, 1996.

Engel, M. and Brückner, H.: The identification of palaeo-tsunami deposits a major challenge in coastal sedimentary research, Coastl. Rep., 17, 65-80, 2011.

Engel, M., Brückner, H., Wennrich, V., Scheffers, A., Kelletat, D., Vött, A., Schäbitz, F., Daut, G., Willershäuser, T., and May, S. M.: Coastal stratigraphies of eastern Bonaire (Netherlands Antilles): New insights into the palaeo-tsunami history of the southern Caribbean, Sediment. Geol., 231, 14-30, 2010.

Folk, R. L. and Ward, W. C.: Brazos River bar [Texas]; a study in the significance of grain size parameters, J. Sediment. Res., 27, 3-26, 1957.

Gaceur, E., Desprat, S., Rouis-Zargouni, I., Hanquiez, V., Lebreton, V., Nebout, N. C., and Kallel, N.: Pollen distribution in surface sediments of the northern Lower Medjerda valley (northeastern Tunisia), Rev. Palaeobot. Palynol., 247, 13-25, 2017.

Goldberg, E. D.: Geochronology with ${ }^{210} \mathrm{~Pb}$, Radioact. Dating, 121, 121-131, 1963.

Hamouda, S.: Etude de l'evolution de l'occupation et de l'utilisation du sol dans le delta de Mejerda par télédétection et SIG, Doctoral dissertation, Faculté des Sciences Humaines et Sociales de Tunis, 2011.

Hawkes, A. D., Bird, M., Cowie, S., Grundy-Warr, C., Horton, B. P., Shau Hwai, A. T., Law, L., Macgregor, C., Nott, J., Ong, J. E., Rigg, J., Robinson, R., Tan-Mullins, M., Sa, T. T., Yasin, Z., and Aik, L. W.: Sediments de- 
posited by the 2004 Indian Ocean Tsunami along the Malaysia-Thailand Peninsula, Mar. Geol., 242, 169-190, https://doi.org/10.1016/j.margeo.2007.02.017, 2007.

Hzami, A., Heggy, E., Amrouni, O., Mahé, G., Maanan, M., and Abdeljaouad, S.: Alarming coastal vulnerability of the deltaic and sandy beaches of North Africa, Sci. Rep., 11, 1-15, 2021.

INP - National Heritage Institute of Tunisia: Une ville antique découverte au large des côtes tunisiennes: Neapolis, available at: http://www.inp.rnrt.tn/index.php?option=com_allvideoshare\& view=video\&slg=httpswwwyoutubecomwatchvpbtcfd9pyeo\& orderby=latest\&lang=fr (last access: 1 December 2021), 2017.

INS - Tunisian National Institute of Statistic: Statistic of the Population Urban growth in the Nabeul Governorate, available at: http://www.nabeul.gov.tn/fr/donnees-generales/ donnees-demographiques/ (last access: 1 December 2021), 2014.

IPCC: Climate Change 2014 Synthesis Report, in: Contribution of working groups I, II, and III to the fifth assessment report of the intergovernmental panel on climate change, edited by: Core Writing Team, Pachauri, R. K., and Meyer, L. A., IPCC, Geneva, Switzerland, 151 pp, 2014.

Karas, J.: Climate change and the Mediterranean region. Report prepared for Greenpeace, Greenpeace International, Amsterdam, 134, 1997.

Jedoui, Y., Kallel, N., Fontugne, M., Ismail, H. Ben, M'Rabet, A., and Montacer, M.: A high relative sea-level stand in the middle Holocene of southeastern Tunisia, Mar. Geol., 147, 123-130, 1998.

Khadraoui, A., Kamoun, M., Hamad, A. Ben, Zaibi, C., Bonnin, J., Viehberg, F., Bahrouni, N., Sghari, A., Abida, H., and Kamoun, F.: New insights from microfauna associations characterizing palaeoenvironments, sea level fluctuations and a tsunami event along Sfax Northern coast (Gulf of Gabes, Tunisia) during the Late Pleistocene-Holocene, J. African Earth Sci., 147, 411-429, 2018.

Khalfaoui, O., Dezileau, L., Degeai, J.-P., and Snoussi, M.: Reconstruction of past marine submersion events (storms and tsunamis) on the North Atlantic coast of Morocco, Nat. Hazards Earth Syst. Sci. Discuss. [preprint], https://doi.org/10.5194/nhess-2019-130, 2019.

KHRYSTAL Engineering: Zone Sensible Littorale de Sidi Ali El Mekki 15, 2003.

Kohila, B. S., Dezileau, L., Boussetta, S., Melki, T., and Kallel, N.: Grain size and geochemeical analysis in the Ghar El Melh Lagoon and the Medjerda River watershed, Zenodo [code and data set], https://doi.org/10.5281/zenodo.5744957, 2021.

Kortekaas, S. and Dawson, A. G.: Distinguishing tsunami and storm deposits: an example from Martinhal, SW Portugal, Sediment. Geol., 200, 208-221, 2007.

Krishnaswamy, S., Lal, D., Martin, J. M., and Meybeck, M.: Geochronology of lake sediments, Earth Planet. Sc. Lett., 11, 407-414, 1971.

Lamb, H.: Climate, History and the Modern World, 2nd Edn., Routledge, London, New York, 1995.

Lambeck, K. and Bard, E.: Sea-level change along the French Mediterranean coast for the past 30000 years, Earth Planet. Sc. Lett., 175, 203-222, 2000.
Latour, E. de Fagues: L'industrie minière en tunisie (1892-1937), État Actuel De L'Exploitation Des Mines Et Des Carrières En Tunisie, 2019.

Lionello, P. and Scarascia, L.: The relation between climate change in the Mediterranean region and global warming, Reg. Environ. Change, 18, 1481-1493, 2018.

Liu, K. and Fearn, M. L.: Reconstruction of prehistoric landfall frequencies of catastrophic hurricanes in northwestern Florida from lake sediment records, Quatern. Res., 54, 238-245, 2000.

Mamo, B., Strotz, L., and Dominey-Howes, D.: Tsunami sediments and their foraminiferal assemblages, Earth-Sci. Rev., 96, 263278, 2009.

MEAT: Communication Initiale de la Tunisie à la Convention Cadre des Nations Unies sur les changements climatiques, Ministère de l'Environnement et de l'Aménagement du Territoire, 2001.

Milanés Batista, C., Galbán Rodriguez, L., and Olaya Coronado, N. J.: Amenazas, riesgos y desastres: visión teórico metodológica y experiencias reales, available at: http://hdl.handle.net/11323/ 1156 (last access: 1 December 2021), 2017.

Morton, R. A., Gelfenbaum, G., and Jaffe, B. E.: Physical criteria for distinguishing sandy tsunami and storm deposits using modern examples, Sediment. Geol., 200, 184-207, 2007.

Moussa, M., Baccar, L., and Ben Khemis, R.: La lagune de Ghar El Melh: Diagnostic écologique et perspectives d'aménagement hydraulique, Rev. des Sci. l'eau, 18, 13-26, 2005.

Oueslati, A.: Les côtes de la Tunisie: géomorphologie et environnement et aptitudes à l'aménagement, Université de Tunis I, Tunis, 1993.

Oueslati, A.: Littoral et aménagement en Tunisie: des enseignements de l'expérience du vingtième siècle et de l'approche géoarchéologique à l'enquête prospective, Publications de la Faculté des Sciences Humaines et Sociales, Université de Tunis, p. 534, 2004.

Oueslati, W., Added, A., and Adeljaouad, S.: "Acide Volatile Sulfides" et "simultaneously extracted metals" dans les sédiments des carottes prélevées dans la lagune de Ghar El Melh, Nord Tunisien, Rev. Méditerr. Env., 1, 15-18, 2006.

Papadopoulos, G. A. and Baskoutas, I.: New tool for the spatiotemporal variation analysis of seismic parameters, Nat. Hazards Earth Syst. Sci., 9, 859-864, https://doi.org/10.5194/nhess9-859-2009, 2009.

Papadopoulos, G. A. and Fokaefs, A.: Strong tsunamis in the mediterranean sea: A re-evaluation, J. Earthq. Technol., 42, 159170, 2005.

Pararas-Carayannis, G.: The earthquake and tsunami of July 21, $365 \mathrm{AD}$ in the Eastern Mediterranean Sea-Review of Impact on the Ancient World-Assessment of recurrence and future impact, Sci. Tsunami Hazards, 30, 253-292, 2011.

Pararas-Carayannis, G. and Mader, C. L.: The earthquake and tsunami of $365 \mathrm{AD}$ in the eastern Mediterranean Sea, in: vol. 25, Proceedings of the 9th US National and 10th Canadian Conference of Earthquake Engineering, 25-29 July 2010, Toronto, Ontario, Canada, p. 29, 2010.

Paris, R., Fournier, J., Poizot, E., Etienne, S., Morin, J., Lavigne, F., and Wassmer, P.: Boulder and fine sediment transport and deposition by the 2004 tsunami in Lhok Nga (western Banda Aceh, Sumatra, Indonesia): A coupled offshore-onshore model, Mar. Geol., 268, 43-54, https://doi.org/10.1016/j.margeo.2009.10.011, 2010. 
Paris, R., Goto, K., Goff, J., and Yanagisawa, H.: Advances in the study of mega-tsunamis in the geological record, Earth-Sci. Rev., 210, 103381, https://doi.org/10.1016/j.earscirev.2020.103381, 2020.

Paskoff, R.: Le delta de la Medjerda (Tunisie) depuis l'Antiquité, Etud. Rurales, EHESS, 15-29, available at: https://www.jstor. org/stable/20125391 (last access: 1 December 2021), 1994.

Paskoff, R. and Trousset, P.: L'ancienne Baie d'Utique: du témoignage des textes à celui des images satellitaires, Mappemonde, 1, 30-34, 1992.

Pausas, J. G. and Millán, M. M.: Greening and Browning in a Climate Change Hotspot: The Mediterranean Basin, Bioscience, 69, 143-151, 2019.

Phadke, R.: Exposing Hurricane Katrina: The Scope of an Unnatural Disaster, Instructor Water and Power (ENVI 294), 2005.

Pirazzoli, P. A.: World atlas of Holocene sea-level changes, Elsevier Oceanogr. Ser., 58, 1-280, 1991.

Raible, C. C., Yoshimori, M., Stocker, T. F., and Casty, C.: Extreme midlatitude cyclones and their implications for precipitation and wind speed extremes in simulations of the Maunder Minimum versus present day conditions, Clim. Dynam., 28, 409-423, 2007.

Reimer, P. J. and McCormac, F. G.: Marine Radiocarbon Reservoir Corrections for the Mediterranean and Aegean Seas, Radiocarbon, 44, 159-166, 2002.

Reimer, P. J., Bard, E., Bayliss, A., Beck, J. W., Blackwell, P. G., Ramsey, C. B., Buck, C. E., Cheng, H., Edwards, R. L., Friedrich, M., Grootes, P. M., Guilderson, T. P., Haflidason, H., Hajdas, I., Hatté, C., Heaton, T. J., Hoffmann, D. L., Hogg, A. G., Hughen, K. A., Kaiser, K. F., Kromer, B., Manning, S. W., Niu, M., Reimer, R. W., Richards, D. A., Scott, E. M., Southon, J. R., Staff, R. A., Turney, C. S. M., and van der Plicht, J.: IntCal13 and Marine13 radiocarbon age calibration curves 050,000 years cal BP, Radiocarbon, 55, 1869-1887, 2013.

Rizzi, J., Gallina, V., Torresan, S., Critto, A., Gana, S., and Marcomini, A.: Regional Risk Assessment addressing the impacts of climate change in the coastal area of the Gulf of Gabes (Tunisia), Sustain. Sci., 11, 455-476, https://doi.org/10.1007/s11625-0150344-2, 2016.

Robbins, J. A. and Edgington, D. N.: Determination of recent sedimentation rates in Lake Michigan using $\mathrm{Pb}-210$ and Cs-137, Geochim. Cosmochim. Ac., 39, 285-304, 1975.

Romdhane, M. S.: Lagune de Ghar El Melh: milieu, peuplement, exploitation, Thèse de doctorat, Tunis, Tunisia, 1985.

Sabatier, P., Dezileau, L., Blanchemanche, P., Siani, G., Condomines, M., Bentaleb, I., and Piquès, G.: Holocene variations of radiocarbon reservoir ages in a Mediterranean lagoonal, Radiocarbon, 52, 91-102, 2010.

Sabatier, P., Dezileau, L., Colin, C., Briqueu, L., Bouchette, F., Martinez, P., Siani, G., Raynal, O., and Von Grafenstein, U.: 7000 years of paleostorm activity in the NW Mediterranean Sea in response to Holocene climate events, Quatern. Res., 77, 1-11, 2012 .
Sahal, A., Roger, J., Allgeyer, S., Lemaire, B., Hébert, H., Schindelé, F., and Lavigne, F.: The tsunami triggered by the 21 May 2003 Boumerdès-Zemmouri (Algeria) earthquake: Field investigations on the French mediterranean coast and tsunami modelling, Nat. Hazards Earth Syst. Sci., 9, 1823-1834, https://doi.org/10.5194/nhess-9-1823-2009, 2009.

Saïdi, H. B., Souissi, R., and Zargouni, F.: Impact of shore-parallel breakwaters on the microtidal coast of Hammam-Lif (North-East of Tunisia), Arab. J. Geosci., 5, 345-352, 2012.

Sakuna-Schwartz, D., Feldens, P., Schwarzer, K., Khokiattiwong, S., and Stattegger, K.: Internal structure of event layers preserved on the Andaman Sea continental shelf, Thailand: tsunami vs. storm and flash-flood deposits, Nat. Hazards Earth Syst. Sci., 15, 1181-1199, https://doi.org/10.5194/nhess15-1181-2015, 2015.

Scardino, G., Piscitelli, A., Milella, M., Sansò, P., and Mastronuzzi, G.: Tsunami fingerprints along the Mediterranean coasts, Rend. Lincei, 31, 319-335, https://doi.org/10.1007/s12210-020-00895W, 2020.

SCET-ERI: Étude de l'amélioration de la qualité de l'eau de la lagune de Ghar El Melh, Rapport d'étude pour le Ministère de l'Agriculture, Tunisie, p. 293, 2000.

Scileppi, E. and Donnelly, J. P.: Sedimentary evidence of hurricane strikes in western Long Island, New York, Geochem. Geophy. Geosy., 8, Q06011, https://doi.org/10.1029/2006GC001463, 2007.

Seisdedos, J., Mulas, J., González de Vallejo, L. I., Rodríguez Franco, J. A., Gracia, F. J., del Río, L., and Garrote, J.: Estudio y cartografia de los peligros naturales costeros de la region de Murcia, Bol. Geol. Min., 124, 505-520, 2013.

Siani, G., Paterne, M., Michel, E., Sulpizio, R., Sbrana, A., Arnold, M., and Haddad, G.: Mediterranean Sea surface radiocarbon reservoir age changes since the last glacial maximum, Science, 294, 1917-1920, 2001.

Stevenson, A. C., Phethean, S. J., and Robinson, J. E.: The palaeosalinity and vegetational history of Garaet el Ichkeul, northwest Tunisia, Holocene, 3, 201-210, 1993.

Tappin, D. R.: Sedimentary features of tsunami deposits - Their origin, recognition and discrimination: An introduction, Sediment Geol., 200, 151-154, https://doi.org/10.1016/j.sedgeo.2007.01.001, 2007.

Tisnérat-Laborde, N., Poupeau, J. J., Tannau, J. F., and Paterne, M.: Development of a semi-automated system for routine preparation of carbonate samples, Radiocarbon, 43, 299-304, 2001.

Zaïbi, C., Kamoun, F., Viehberg, F., Carbonel, P., Jedoui, Y., Abida, H., and Fontugny, M.: Impact of relative sea level and extreme climate events on the Southern Skhira coastline (Gulf of Gabes, Tunisia) during Holocene times: Ostracodes and foraminifera associations' response, J. African Earth Sci., 118, 120-136, 2016.

Zoppi, U., Albani, A., Ammerman, A. J., Hua, Q., Lawson, E. M., and Barbero, R. S.: Preliminary estimate of the reservoir age in the lagoon of Venice, Radiocarbon, 43, 489-494, 2001. 